\title{
Osmanlı Devlet Teşkilâtında Yargının İdari Denetimi: Kadıasker Teftiş Örneği
}

\section{Administrative Supervision of the Judiciary in the Ottoman State Organization: Inspection Example About Qadiasker}

\author{
Cihan KILIÇ \\ Dr. Öğr. Üyesi, Ankara Sosyal Bilimler Üniversitesi, İslami ilimler Fakültesi, İslam Tarihi Anabilim Dalı \\ Assistant Professor, Social Sciences University of Ankara, Faculty of Islamic Sciences, \\ Department of Islamic History \\ Altındağ/Ankara, Turkey \\ cihan.kilic@asbu.edu.tr \\ orcid.org/0000-0002-5216-183X
}

\author{
Makale Bilgisi / Article Information \\ Makale Türü / Article Types \\ : Araştırma Makalesi / Research Article \\ Geliş Tarihi / Received \\ : 27 Eylül / September 2019 \\ Kabul Tarihi / Accepted \\ : 29 Kasım / November 2019 \\ Yayın Tarihi / Published \\ : 15 Aralık / December 2019 \\ Yayın Sezonu / Pub Date Season : Aralık / December \\ Cilt / Volume: 6 - Sayı / Issue: 2 - Sayfa / Pages: 333-365
}

\section{Atıf / Cite as}

Kılıç, Cihan. “Osmanlı Devlet Teşkilâtında Yargının İdari Denetimi: Kadıasker Teftiş Örneği”. Bülent Ecevit Üniversitesi Illahiyat Fakültesi Dergisi, 6/2 (2019): 333-365

Doi: 10.33460/beuifd.626012

İntihal / Plagiarism

Bu makale, en az iki hakem tarafından incelendi ve intihal olmadığı teyit edildi.

This article has been reviewed by at least two referees and scanned via a plagiarism software.

Yayın Hakkı / Copyright ${ }^{\circ}$

Zonguldak Bülent Ecevit Üniversitesi, İlahiyat Fakültesi tarafından yayınlanmıştır. Tüm hakları saklıdır.

Published by Zonguldak Bulent Ecevit University, Faculty of Theology, Zonguldak, Turkey. All rights reserved.

Öz: Adalet teşkilâtının düzenli işleyebilmesi, adaletin temini için gerekli şartların sağlanmasının yanı sıra muhtemel aksaklıklar ve bunlara bağlı olarak gelebilecek şikâyetlerin dikkate alınmasına bağlıdır. Osmanlı Devleti de adalet teşkilâtına önem vermiş devletin her tarafına yayılan kadılık teşkilâtı ve bir yönüyle üst mahkeme sayılan Dîvân-ı Hümâyun ile adaleti tesis etmeye çalışmıştır. Adalet teşkilâtının iş ve işlemlerini yerine getiren kadılar ile bu teşkilâtın insan kaynağını yetiştirme görevini üstlenen medreseler, ilmiye teşkilâtı adı altında organize edilmiştir. Illmiye teşkilâtının iş ve işlemleri ise Kadıaskerler tarafından organize edilmiştir. Kadıaskerler adalet sisteminin başında bulunsa da onların yaptığı faaliyetler zaman zaman şikâyete konu olmuştur. Özellikle görevden ayrıldıktan sonra veya haklarında şikâyet olması durumunda Kadıaskerlerin faaliyetleri görevlendirilen üst düzey ulemâ tarafından tetkik edilmekte, haklarında mahkeme kurulmaktadır. Bu çalışmada Rumeli Kadıaskeri hakkında merkezi yönetim tarafından görevlendirilen müfettişin gördüğü davalar konu edilmiştir.

Anahtar Kelimeler: Osmanlı Tarihi, Kadıasker, Ilmiye, Ulema, Adalet, Kadı 
Abstract: The regular functioning of the judicial organization depends on ensuring the necessary conditions for the provision of justice as well as considering possible inconveniences and the possible complaints that may arise. The Ottoman Empire attached importance to the judicial organization and tried to establish justice with the judiciary (qadi) organization spreading all over the state and Dîvân-ı Hümâyun, which was considered as the upper court in one aspect. The qadis who carried out the tasks and operations of the judicial organization and the madrasas that undertook the responsibility of training the human resources of this organization were promoted under the name of "ilmiye" organization. The task and operations of the IImiye organization were promoted by Qadiasker. Although the Qadiasker were the head of the judicial organization, their activities have sometimes been subject to complaints. Especially after resignation or in case of complaints, the activities of the Qadiaskers were inspected by the appointed senior ulama and were sued at the court. This study discusses the cases about the Qadiasker of Rumeli which were realized by the inspector appointed by the central administration.

Key Words: Ottoman History, Qadiasker, Ilmiye, Ulama, Justice, Qadi

\section{Giriş̧}

Osmanlı Devleti adalet teşkilâtına önem vermiş onun sağlıklı işleyebilmesi için gerekli kurumları devletin ilk yıllarından itibaren teşekkül ettirmiştir. Bu kapsamda kadılık teşkilâtı ile topraklarının her tarafında adaleti sağlamaya çalışmıştır. Adaleti sağlamakla görevli kadıların atanmasını ve görevlerinin suistimale uğramadan devam etmesini önemsemiştir. Kadılık kurumunun yanı sıra bu kuruma insan kaynağı sağlayan tedris görevini üstlenen medrese teşkilâtına da önem verilmiş ve her iki kurumun iş ve işlemleri ilmiye teşkilâtı adı altında organize edilmiştir.

Illk kadı olarak Dursun Fakih¹ (ö. 1326), ilk müderris olarak Davud-ı Kayseri² (ö. 1350) atandıktan sonra gerek kadılık kurumu gerekse müderrislik mesleği teşkilâtı Fatih dönemine kadar çeşitli aşamalardan geçerek kurumsal teşkilatlanmasını tamamlamış, Kanuni döneminde klasik şekline ulaşmıştır. ${ }^{3}$ Bu bağlamda kuruluş yıllarında Bursa kadısı tarafından düzenlenen süreç, ${ }^{4}$ Çandarlı Kara Halil Paşa'nın (ö. 1387) ilk Kadıasker olarak ilmiye sınıfının başına atanması ile hızlanmıştır. ${ }^{5}$ Kadıaskerlik makamı devletin büyümesi ile iş ve işlemlerinin çoğalması sonucu Fatih Sultan Mehmed döneminde, Karamanî Mehmed Paşa'nın arzı ile Anadolu

1 Aşıkpaşazâde, Âşıkpaşaoğlu Tarihi, nşr. Atsız (İstanbul: Milli Eğitim Bakanlığı Yayınları, 1992), 25; Hasan Aksoy, "Dursun Fakih", Türkiye Diyanet Vakfı İslâm Ansiklopedisi (İstanbul: TDV Yayınları, 1994), 10: 7-8.

2 Mehmet Bayraktar, "Dâvûd-i Kayserî", Türkiye Diyanet Vakfı İslâm Ansiklopedisi (İstanbul: TDV Yayınları, 1994), 9: 33.

3 Hasan Akgündüz, Klasik Dönem Osmanlı Medrese Sistemi (Amaç, Yapı, İ̧leyiş) (İstanbul: Ulusal Yayınları, 1997), 260.

4 Mehmet İpşirli, “Anadolu Kadıaskeri Sinan Efendi Hakkında Yapılan Tahkikat ve Bunun İlmiye Teşkilâtı Bakımından Önemi", İlâm Tetkikleri Dergisi 8/1-4 (1984): 205.

5 Münir Aktepe, "Çandarlı Kara Halil Hayreddin Paşa", Türkiye Diyanet Vakfı İslâm Ansiklopedisi (İstanbul: TDV Yayınları, 1993), 8: 215. 
ve Rumeli Kadıaskerliği olarak ikiye ayrılmıştır. ${ }^{6}$ Yavuz Sultan Selim döneminde Diyarbakır merkezli Arap ve Acem Kadıaskerliği kurulduysa da sonrasında bu üçüncüsü kapatılmış ve Anadolu Kadıaskerliği bünyesinde faaliyet yürütmüştür.?

Devletin hemen her köşesine yayılmış, dolayısıyla taşrada devletin en önemli temsilcilerinden olan kadılık ve müderrislikgibi kurumların Kadıaskerlik makamına bağlı olması bu makamın önemini göstermektedir. Şeyhülislâmlık makamının Ebussuud Efendi döneminde önem bakımdan birinci sıraya geçmesine kadar kadı ve müderris atamalarının tümünün arzını gerçekleştiren Kadıaskerlik makamı, ${ }^{8}$ bu tarihten sonra mülâzemet kayıtlarını tutmanın yanı sıra 20-25-30 ve 40 akçe yevmiye alan müderris atamalarının ${ }^{9}$ ve mevleviyet derecesine kadar olan kadı atamalarının arzını gerçekleştirmiştir. ${ }^{10}$ Ebussuud Efendi'den sonra Şeyhülislâmlık makamı atama iş ve işlemlerinin bir kısmını üstlendiyse de nicel olarak görev yükünün çok önemli bir kısmı hala Kadıaskerler üzerinden devam etmiş̧tir. ${ }^{11}$

Osmanlı Devleti'nde herhangi bir şekilde haksızlığa uğrayan veya uğradığını düşünen kişiler öncelikle mahalli kadılara başvururlardı. Bu başvurularında da adaletin tam tesis edilmediğini düşünürlerse taşrada bir itiraz mercii bulunmamakla birlikte ${ }^{12}$ kadıların hükümlerini ve diğer konuları şikâyet için en üst temyiz makamı olan Dîvân-ı Hümâyun'a başvurmaları mümkündü. Kadının hükmünü beğenmeyenler, askeri sınıflardan şikâyetçi olanlar ile diğer davalar

6 İkiye ayrılma olayını Karamanî Mehmed Paşa'nın, Kadıasker Mevlanâ Müslihiddin Efendi'nin etkisinden çekindiği için gündeme getirdiği ve Fatih Sultan Mehmed'i ikna ettiği belirtilse de Fatih dönemi teşkilât yapısının doğal sonucu olma ihtimali daha kuvvetlidir. Belki bu bireysel çekişme ikiye ayrılma sürecini hızlandırmıştır (Mehmet İpşirli, “Osmanlı Devleti'nde Kadıaskerlik (XVII. Yüzyıla kadar)”, Belleten 61/232 (Aralık 1997): 610.

7 İdris-i Bitlisi, Heşt Behişt VII. Ketibe, Fatih Sultan Mehmet Devri (1451-1481), nşr. Muhammed İbrahim Yıldırım, (Ankara: Türk Tarih Kurumu Yayınları, 2013), XXXVII; İpşirli, “Osmanlı Devleti'nde Kadıaskerlik”, 598.

8 Halil İnalcık, Osmanlı Imparatorluğu Klâsik Çağ (1300-1600), trc. Ruşen Sezer (İstanbul: Yapı Kredi Yayınları, 2013), 179.

9 Abdurrahmân Abdî Paşa, Abdurrahmân Abdî Paşa Kanunnâmesi, nşr. H. Ahmet Arslantürk (i̇stanbul: Okur Kitaplığı Yayınları, 2012), 60.

10 Kadıasker atamalarının kapsamı ile ilgili detaylı bilgi için bk. Yasemin Beyazıt, Osmanlı Ilımiye Mesleğinde Istihdam (XVI. yüzyıl) (Ankara: TTK, 2014); Ercan Alan, Kadıasker Ruznamçelerine göre XVII. Yüzyılda Rumeli'de Kadılık Müessesesi (Doktora Tezi, Marmara Üniversitesi, 2015); Levent Kuru, Kazasker Ruznamçelerine Göre XVIII. Yüzyılın IIlk Yarısında Rumeli'de Kadılık Müessesesi (Doktora Tezi, Marmara Üniversitesi, 2016); Cihan Kılıç, Osmanlı IImmiye Teşkilâtında Istihdam ve Hareket (Anadolu Kadıaskerliği Örneği) (Doktora Tezi, Yıldırım Beyazıt Üniversitesi, 2017).

11 Cahid Baltacı, XV ve XVI. Yüzyıllarda Osmanlı Medreseleri (İstanbul: M.Ü. İlahiyat Fakültesi Vakfı, 2005), 1/139.

12 "Islam hukukunda temyiz kurumu yoktur. Kadının verdiği hüküm kesindir. Bu nedenle temyiz ya da istinaf hatta bugünkü anlamıyla karar düzeltme gibi kavramlar İslam hukukunda yerleşmemiştir." (Ahmet Mumcu, Hukuksal ve Siyasal Karar Organı Olarak Divan-ı Hümayun (Ankara: Birey ve Toplum Yayınları, 1976), 91). Dolayısıyla klasik dönemde belli bir sistematiği olan temyiz uygulamasından bahsetmek zordur (Mustafa Şentop, Osmanlı Yargı Sistemi ve Kazaskerlik (İstanbul: Klasik Yayınları, 2005), 118). 
için Dîvân kapısı her zaman açıktı. ${ }^{13}$ Dîvân-ı Hümâyun'da şer'i davalara Rumeli Kadıaskeri bakardı. Yerinde denetim ise müfettişler aracılığı ile gerçekleştirilirdi. Bu denetimler bazen Beylerbeyi bazen de Sancak Beyi ile beraber yapılırdı. ${ }^{14}$ Ancak yargılamadaki sorumluluk yine kadıya aitti.

Kadıların denetlenmesi komşu kadılıklarca veya merkezden görevlendirilen ilmiye sınıfı üyeleri aracılığıyla yapılırdı. Bu işlem için infisâldeki ${ }^{15}$ meslek mensupları kullanılırdı. ${ }^{16}$ Mehayif müfettiş̧i ${ }^{17}$ adı ile görevlendirilen kadılar, özellikle şikâyet gelen bölgelere görevlendirilirler ve buralarda kadı ile naiplere aldırış etmeden dava görürler, yaptıkları işler için doğrudan Dîvân-ı Hümâyun'a bilgi verirlerdi. Bazen de şikâyete konu olan kadılar davaları görülmek üzere Dîvân-ı Hümâyun'a gönderilirlerdi. ${ }^{18}$ Ayn şsekilde müderrisler de çeşitli sebeplerle şikâyetlere konu olurlar ve teftiş geçirirlerdi. ${ }^{19}$

Kadı ve müderrislerin uygulamaları şikâyete konu olduğu gibi bu şikâyetleri Dîvân-ı Hümâyun adına tahkik eden Kadıaskerlerin de faaliyetleri özellikle idari yönden şikâyete konu olmaktaydı. ${ }^{20}$ Şikâyetler daha çok mülâzemetle ${ }^{21}$ ilgili olmakla birlikte kadı ve müderris atamaları hakkındadır. Kadı ve müderris atamaları sadece mağdur kişiler tarafından değil devletin teşkilâtı hakkında görüş

13 Kağıt üzerinde zengin ya da yoksul Müslüman ya da gayri Müslüm ve de hangi toplumsal sınıftan olursa olsun Sultan'ın uyruğu davasını Dîvân-ı Hümâyun'a sunabilirdi. Ancak uygulamada bir davayı Dîvân-ı Hümâyûn huzuruna çıkarmak büyük mali yatııım gerektirmekteydi. Dîvân'a getirilen vesikalı kanıtlar genellikle şeriyye mahkemelerinin hüccetleri şeklinde sunulmalıydı ve başvurular Dîvân'a yazııı olarak yapılmadıydı bu da şikâyetçinin bizzat başkente gelmesi veya vekilini tayin etmesi gerekliliğini gösterir. Söz konusu durum da belli bir mali külfet getirmektedir (Maurits H. van den Boogert, Kapitülasyonlar ve Osmanlı Hukuk Sistemi 18. Yüzyılda kadılar, konsoloslar ve beratılıar, trc. Ali Coşkun Tuncer (İstanbul: Türkiye Iş̧ Bankası Yayınları, 2014), 47).

14 Mustafa Şentop, Osmanlı Devleti'nde Kazaskerlik Kurumu (XVII. Yüzyılın Sonuna Kadar) (Doktora Tezi, Marmara Üniversitesi, 2002), 122.

15 İnfisâl: İlmiye teşkilâtında bir görevden diğerine atanma esnasında beklenilen süreyi ifade etmektedir.

16 Stanford J. Shaw, Osmanlı Imparatorluğu ve Modern Türkiye, trc. Mehmet Harmancı (İstanbul: e Yayınları, 2008), I: 176.

17 Mehayif müfettişi: Bir kadının faaliyetlerini denetlemek amacıyla görevlendirilen diğer ilmiye mensubuna verilen isim.

18 İsmail Hakkı Uzunçarşılı, Osmanlı Devleti'nin IIlmiye Teşkilâtı (Ankara: Türk Tarih Kurumu Yayınları, 2014), 133.

19 Şentop, Osmanlı Yargı Sistemi ve Kazaskerlik, 106.

20 Bu durumla ilgili örneklere Kadıasker ruznamçe defterlerinde de rastlamak mümkündür. Örneğin Anadolu Kadıaskeri Mustafa Efendi el-Bursevî'ye hitaben kadıların şikâyeti üzerine yazılmış bir emir şu şekildedir: "İzzetli fazîletli Anadolu Kâdı'askeri Efendi hazretleri, Kuzât-ı Anadolu'dan birkaç nefer kadı selefleri olan Mehmet Said Efendi'den şikâyet idüb kendüleri Âsîtâne'ye mülâzemette iken asla mülâzemeti olmayanların hilâf-ı kânûn ve mugâyır-ı hatt-ı hümâyûn ayaklarına mansıb gönderip mülâzemette olup menâsıba müstehak olan fukahanın mağdur olduklarını i'lâm eyledikleri filhakîka olmakûle hilâf-ı kânûn menâsıb tevcîh edip tevcihi müstehak olanları sıfrulyed kalûb gadr olundukları vaki' ise tevcîh eylediğine asıl mansubdır ve tevcîhle fuhakâ-i kuzâta gadr olunmuş ahvâllerini mübeyyin defter idüb huzûrunuza arz eyleyesiz deyû 3 Şaban 1085".

"İzzetli fazîletli Anadolu Kâdı'askeri, hilâf-ı kânûn ve mugâyır-ı hatt-ı hümâyûn eğer bilâ mülâzemete tevcîh olunanlar ve eğer ecnebî olanları ve tensîb olunanları 'an asl ilgâ idüb mülâzemeti olan müstehakikîne tevcîh idüb vukû' ve mülgât olanlara ne müddetten ve ne vechile tevcîh olunmuş ise müstahak olanlara kezalik öyle tevcîh idüb kânûn üzre temessüklerin veresiz deyû fi 28 Şaban 1085" (Nuruosmaniye Kütüphanesi (NOK), Anadolu Kadıaskerliği Ruznamçesi (AKR), 5193/11, Vr. 1).

21 Mülâzemet: ilmiye teşkilâtına girişte beklenilen zamanı ve bir görevden diğerine atanırken beklenilen zamanı ifade etmektedir (bk. Beyazıt, Osmanlı Illmiye Mesleğinde İstihdam, 28). Bu çalışmada daha çok birinci anlamı ile kullanılmıştır. 
bildiren rical tarafından da dile getirilmiştir.22 Bu konudaki en ağır eleştirilerden biri Mustafa Âli tarafından yapılmaktadır. O, ilmiye teşkilâtının 1001/1592-3 yılından itibaren bozulduğunu rüşvet sebebiyle mülâzemet sisteminin tahribata uğradığını ve adam kayırmanın temel problem olduğunu ifade etmektedir. ${ }^{23}$ Koçi Bey ise mülâzımlıkların iltimas yüzünden ehil olmayan kişilere verilmesinden Kadıaskerleri sorumlu tutmaktadır. ${ }^{24}$ Yine Kadıaskerlerce gerçekleştirilen kadı ve müderris atamalarına ilişkin itirazlar sık sık dile getirilmektedir. ${ }^{25}$

Kadıaskerlerin görevlerini gereği gibi yerine getirmemeleri üzerine azledilmeleri ve bu azli takiben uygulamalarının denetlenmesi mümkün olmakla birlikte kaynaklarımızda bu gibi hususlara ait kayıtlara pek rastlanmamaktadır. Kadıasker teftişine dair en detaylı bilgilere Anadolu Kadıaskeri Sinan Efendi'nin Fatih camiinde devam eden ve sonunda temize çıkması ile sonuçlanan tahkikattan ulaşabiliyoruz. ${ }^{26}$ Burada Sadece Sinan Efendi değil Rumeli Kadıaskeri Bostan Efendi ${ }^{27}$ ve İstanbul Kadısı Saçlı Emir Efendi'de (ö. 963/1555-6) teftiş edilmiş ancak hepsi temize çıkmıştır. Atâyî'nin belirttiğine göre bu üç âlim Rüstem Paşa'nın onlara şahsi kini yüzünden haksızlığa uğramışlardır. ${ }^{28}$ Bu durum teftişin idari baskı aracı olarak kullanıldığını ancak davaya müdahil olunamadığını göstermektedir. Bir diğer Kadıasker yargılaması ise Şam kazasından ma'zul olan Kadı Şemseddin'in Rumeli Kadıaskeri Hâmid Efendi için yaptığı teftiştir. ${ }^{29}$ Ancak bu teftişle ilgili detaylı bilgilere henüz sahip değiliz. Söz konusu kayıtlara ulaşılması ile sadece davaya konu olan hususlar hakkında değil verilen cevaplar ve şikâyete konu olan durumlardan yola çıkılarak ilmiye teşkilâtının işleyiş̧i hakkında da kıymetli bilgiler edinmemiz mümkün olacaktır.

\section{TEFTiŞ DEFTERi}

$\mathrm{Bu}$ araştırmanın konusu olan teftiş defterinin yazılış amacı belgenin giriş kısmında açıkça ifade edilmektedir: Buradan anlaşıldığına göre defteri kaleme

22 Bu bozulma ve sebepleri hakkında bir değerlendirme için bk. Yasemin Beyazıt, "XVI. Yüzyıl Osmanlı İlmiyye Kanûnnâmeleri ve Medrese Eğitimi", Belleten LXXVIII/283 (2014).

23 Gelibolulu Mustafa Âlî, Mevâ'idü'n-Nefâis Fî-Kavâ' di'l-Mecâlis, nşr. Mehmet Şeker, (Ankara: Türk Tarih Kurumu Yayınları, 1997), 314-316.

24 Koçi Bey, Koçi Bey Risalesi, nşr. Yılmaz Kurt (Ankara: Akçağ Yayınları, 1998), 43.

25 Zeki Salih Zengin, "Osmanlı Medreselerindeki Gerilemenin Sebep ve Sonuçları Üzerine Bir değerlendirme”, Vakıflar Dergisi, 26 (1997), 404.

26 Mehmet İpşili, “Anadolu Kadıaskeri Sinan Efendi Hakkında Yapılan Tahkikat", 205-218.

27 Bostan Efendi 932/1526 senesinde mülâzemete nail olmuş, 935/1529'de Bursa Molla Yegan Medresesi'ne müderris olarak görevlendirilerek ilmiye tarikine dahil olmuştur. Çeşitli medreselerde görev yaptıktan sonra sırasıyla Bursa, Edirne ve İstanbul Kadılığı görevinde bulunmuştur. 954/1547 senesinde önce Anadolu sonra Rumeli Kadıaskerliği görevlerine getirilmiştir.16 Şevval 958/17 Ekim 1551 tarihine kadar bu görevde kalmış çeşitli müfettişlik görevlerinde bulunduktan sonra 27 Ramazan 977/5 Mart 1570 tarihinde vefat etmiştir (Nev'îzâde Atâyî, Hadâ'iku'I-Hakâ'ik Fî Tekmileti'ş-Şakâ'ik (Nev'izâde Atâyi'nin Şakâ'ik Zeyli), nşr. Suat Donuk, (İstanbul: Türkiye Yazma Eserler Kurumu Başkanlığı Yayınları, 2017), I: 527-531).

28 Veziriazam Rüstem Paşa ile Vezir Haydar Paşa arasındaki bir davada Haydar Paşa'nın haklı olduğuna hükmetmesi üzerine 1551 'de görevinden alınmışlar ve haklarında davalar açılmıştır (Atâyi, Hadâ'iku'l-Hakâ'ik, 529).

29 Türkiye Cumhuriyeti Cumhurbaşkanlığı Devlet Arşivleri Başkanlığı Osmanlı Arşivleri (BOA), Topkapı Müzesi Arşiv Defterleri (TS.MA.d), 5789/1, Vr. 003. 
alanın denetlenmesi için hükm-i şerîf uyarınca teftiş meclisi kurulmuştur. Teftiş esnasında davacıların davaları yazılmakta ve bunlara detaylı cevaplar verilmektedir. Teftiş edilen kişi (aşağıda makamı ve kendisi hakkında tartışmaya yer verilmiştir) teftiş esnasında verdiği cevapların olduğu gibi yazılıp yazılmadığını kontrol amacıyla kayıtları görmek istemekte ve kayıtların bir örneğini de talep etmektedir. Ancak talebi kabul edilmediğinden şikâyetçilerin ifadelerini ve verdiği cevapları kendisi ayrıntılı olarak kaydetmiştir. Elimizdeki belge teftişe tâbi tutulanın kendi tuttuğu kayıtları ihtiva etmektedir. Asıl teftiş metnine ise yapmış olduğumuz araştırmalar sonucunda henüz ulaşılamamıştır.

Teftiş belgesinde, belgenin tarihi ve kim tarafından kaleme alındığına dair net ifadeler bulunmamaktadır. Bununla ilgili gerek metnin içeriğinden gerekse Osmanlı Arşivi Daire Başkanlığı'ndan elde edilen bilgiler doğrultusunda yorum yapmak mümkündür. Dört varak-yedi sayfadan oluşan belge, Türkiye Cumhuriyeti, Cumhurbaşkanlığı Devlet Arşivleri Başkanlığı, Osmanlı Arşivlerinde Topkapı Müzesi Arşiv Defterleri kataloğunda 5789 numara ve 21 Safer 974/7 Eylül 1566 tarihi ile kayıtlıdır. Ancak belgenin içerisinde bu net tarih zikredilmemiştir. Arşiv kayıtlarında Topkapı Sarayındaki belgelerin çuvallar içerisinde tarihlenmiş ve mühürlenmiş olduğu, bu çuvallardan çıkan belgelerin kataloglanırken bu tarihlerin esas alındığı belirtilmektedir. Teftiş evrakı muhtevasında net tarih bulunmasa da tarihlendirmede kullanılacak birtakım bilgiler bulunmaktadır. Bunlardan birisi önceki Kadıaskerlerden bahsederken ismi geçen Rumeli Kadıaskeri Muhyiddin Çelebi ${ }^{30}$ (ö.1548) diğeri ise Anadolu Kadıaskeri Mevlânâ

30 Muhyiddin Çelebi, ilk Şeyhülislam Molla Fenari'nin torunlarındandır. Çeşitli medreselerdeki müderrislik görevinden sonra kadılık mesleğine geçerek 925/1519'da Edirne, 926/1520'de İstanbul kadılığına getirildi. 929/1523'te Anadolu Kadıaskeri, 930/1524'te Rumeli kazaskeri oldu. Bu görevde iken Vezîriâzam Pîrî Mehmed Paşa yerine Vezîriâzam olmak isteyen Hain Ahmed Paşa'nın tertibiyle, Mısır'dan vaktiyle sürülenlerden rüşvet alıp gitmelerine izin verdiği yolunda yapılan şikâyetleri teftişe görevlendirildi. Kaynakların belirttiğine göre Hain Ahmed Paşa taraftarı olan Muhyiddin Çelebi bu soruşturmada adaletsiz davranmış ve teftişi Pîrî Mehmed Paşa'nın aleyhine sonuçlandırmıştı. Pîrî Mehmed Paşa'nın hizmetinde bulunmuş olan Celâlzâde Mustafa Çelebi bu olay dolayısıyla, Muhyiddin Çelebi'nin zulüm ehline tâbi olarak "nakd-i adli zâyi ettiğini" yazar. Ancak bu iktidar mücadelesinde Hain Ahmed Paşa'nın uzaklaştırılıp vezîriâzamlık makamına Makbul İbrâhim Paşa'nın tayinini desteklediği anlaşılan Muhyiddin Çelebi, daha sonra Molla Kâbız olayındaki yetersizliği sebebiyle İbrâhim Paşa'nın ve Padişahın gazabına uğradıysa da görevini sürdürdü. Fakat Molla Kâbız'ın iddialarını Anadolu kazaskeri Kadirî Çelebi ile birlikte şer'î olarak reddetme hususunda yetersiz kalmaları Muhyiddin Çelebi'nin prestijini çok sarstı. Veziriazam Ayas Pâşâ nın vefatı ile (1539) yeniden nüfuzunu arttırmaya başladı. 949/1543'te Şeyhülislam oldu. İki yıl on ay bu makamda kaldıktan sonra yaşlılığı sebebiyle ve kendi arzusuyla görevinden ayrıldı. (Müstakimzade Süleyman Saadeddin, Devhat ül-Meşayih, Osmanlı Şeyhülislamlarının Biyografileri (İstanbul: Çağrı Yayınları, 1978), 22-23; Mehmet İpşirli, "Fenarîzâde Muhyiddin Çelebi", Türkiye Diyanet Vakfı İslâm Ansiklopedisi (Ankara: TDV Yayınları, 1995), 12: 340). 
Sinan Efendi'dir ${ }^{31}$ (ö.1578). Muhyiddin Çelebi 1524-1539 tarihleri arasında Rumeli Kadıaskerliği, Mevlânâ Sinan ise 1547-1551 tarihleri arasında Anadolu Kadıaskerliği yapmıştır. Dolayısı ile söz konusu defterin bu tarihlerden sonraki bir döneme aidiyeti kesindir. Defterin kataloğunda yer alan 974/1566 tarihinin doğru olması teftiş defterinin içeriğindeki bilgilerden de hareketle muhtemeldir.

Müphem olan diğer konu defterin kime ait olduğudur. Teftiş konularına bakıldığında büyük bir kısmının kadı ve müderris atamaları ile alakalı olduğu görülmektedir. Söz konusu atamaların belgenin kaleme alındığı devirde üç makamın uhdesinde olduğu bilinmektedir. 300 veya 499 akçeye kadar kadılıklar ile 40 akçeye kadar müderris atama arzları Kadıaskerlerin uhdesinde, 500 akçelik Mevâlî kadılıkları ile 50 akçe ve üzeri müderris atama arzları Şeyhülislâm görev sahasında bulunmaktadır. ${ }^{32} \mathrm{Bu}$ bilgilerden hareketle defterde şikâyete konu olan atamalar Kadıaskerin yetki sahasında bulunan kadılıklar ve medreselerdir. Ayrıca defterde birkaç yerde geçen "bu fakîrin tezkirecisi"33 tabiri de tezkirecinin ${ }^{34}$ kadıaskerin yardımcısı olmasından dolayı Kadıaskere ait olduğunu ispatlamaktadır. Defterin Rumeli Kadıaskerine ait olduğu ise kadılıklar ile medreselerin bulundukları yerlerden (Edirne Çukacı Medresesi, Gelibolu Saruca Paşa Medresesi, Siroz, Dimetoka, Malkara, İstanköy, Hurpeşte kazâları...) ve metinde geçen "Anadolu Kadıaskerine gönderelim müşâvere edelim", "Anadolu Kâdıaskeri ile ma'â imtihân edib"35 gibi ifadelerden anlaşılmaktadır.

Teftiş belgesinin katalog tarihi olan 21 Safer 974 / 7 Eylül 1566 tarihinde görevde bulunan Rumeli Kadıaskeri Çivizâde Damadı Hâmid Efendi'dir. ${ }^{36}$ Nev'izâde Atâ'î ve İlmiye Salnamesi kayıtlarına göre Şevval 964 / TemmuzAğustos 1557 tarihinden 3 Rebiülahir 974 / 18 Ekim 1566 tarihine kadar Hâmid Efendi Rumeli Kadıaskerliği makamında görev yapmıştır. Katalog tarihinin teftiş tarihi olarak kabul edilmesi durumunda teftişin, Ebussuud Efendi'den sonra

31 Mevlânâ Sinan Efendi, 893/1488 tarihinde dünyaya geldi. 928/1522'den itibaren müderrislik, 946/1539'dan itibaren kadılık yaptı. Şâban 954/1547'de İstanbul kadısı ve on gün sonra Anadolu kazaskeri oldu. Kanûnî Sultan Süleyman ile birlikte Elkâs (Tebriz) seferine katıldı (955/1548). Değirmen (âsiyâb) vak'ası sırasında (Şâban 958/ Ağustos 1551) Rumeli kazaskeri ve İstanbul kadısı ile birlikte görevinden azledildi. Bu arada hacca giden Sinan Efendi, hakkında yapılan teftiş sonunda temize çıktı. Rebîülâhir 969/Aralık 1561'de Süleymaniye Dârülhadisi müderrisliğine tayin edildi. Ebüssuûd Efendi'nin vefatı üzerine (982/1574) şeyhülislâmlık makamına geçmesi yönündeki teklifi kabul etmedi. Safer 983/Mayıs 1575'te yaşlıı̆ı sebebiyle vazifeden ayrıldı ve 12 Safer 986/20 Nisan 1578 tarihinde İstanbul'da vefat etti (Eyüp Said Kaya, "Sinan Efendi", Türkiye Diyanet Vakfı İslâm Ansiklopedisi (Ankara: TDV Yayınları, 2009), 37: 229).

32 Uzunçarşılı, Osmanlı Devleti'nin IImiye Teşkilâtı, 159; Kılıç, Osmanlı Illmiye Teşkilâtında İstihdam ve Hareket, 227; Beyazıt, Osmanlı IImiye Teşkilâtında İstihdam, 10.

33 BOA, TS.MA.d, 5789/1, Vr. 002.

34 Tezkireci: Kadıasker kaleminin amiri olup kadıların tevcih beratları bu kalemden çıkardı (Uzunçarşılı, Osmanlı Devleti'nin Illmiye Teşkilâtı, 158).

35 BOA, TS.MA.d, 5789/1, Vr. 003.

36 Hamid Efendi, 900/1594 yılında Konya'da doğdu. Çivizâde Muhyiddin Efendi'nin öğrencisi ve damadı oldu. Tezkirecilik görevinden sonra çeşitli medreselerde müderrislik yaptı. 963/1556 yılında İstanbul kadılığına ve sonrasında Rumeli Kadıaskerliğine (964/1557) getirildi. Dokuz buçuk yıl bu görevde kaldı. Sekiz yıl süren ma'zuliyetten sonra Şeyhülislam makamına Ebussuud Efendi'den sonra getirildi. Bu görevde iken 3 Şâban 985/16 Ekim 1577 'de vefat etti (Atâ'î, Hadâ'iku'l-Hakâ'ik, 764-766). 
Şeyhülislâmlık makamına getirilen, o dönemde Rumeli Kadıaskeri olan Hâmid Efendi'nin Rumeli Kadıaskerliği döneminde yapılmış olması gerekmektedir.

Teftiş tarihi Kanuni Sultan Süleyman'ın ölümünden (20 Safer 974/ 6 Eylül 1566) bir gün sonrasını göstermektedir. Hâmid Efendi, Kanuni'nin son seferi olan Zigetvar seferinde bulunmuş ve Belgrad'da iken emekliye sevk edilmiştir. ${ }^{37}$ Emekliye sevk edilmesinin bu teftiş sonucu olup olmadığı belirsizdir. Ancak Selanikî'nin belirttiğine göre Zigetvar seferinden dönülürken Kanuni Sultan Süleyman zamanındaki içki yasağının devam etmesini isteyen Hâmid Efendi'nin bu yüzden yeni Padişah II. Selim tarafından görevden alındığı rivayet edilmektedir. ${ }^{38}$ Eğer anlatılan olay doğruysa, Kadıaskerin böyle bir sebeple görevden alınması huzursuzluğa yol açabileceğinden görevden alınması için daha makul bir sebep bulunması gerekecektir. Bu gerekçenin teftiş neticesi elde edilmek istenmesi mümkündür. Belgenin girişinde yazılış gerekçesi olarak teftişe gelenlerin mahkeme tutanaklarını vermemeleri gösterilmektedir. Hâmid Efendi'nin azil tarihi de 18 Ekim 1566 tarihi olduğundan azlin gerekçesi olarak söz konusu teftişin gösterilmesi ihtimal dahilindedir.

Bununla beraber teftiş belgesinde geçen Mevlânâ Muhyiddin'in yargılanmasında geçen "azlimizden 1 ay önce risale getirdi"39 ifadesinden hareketle defteri kaleme alan Kadıaskerin katalog tarihinde görevde olmadığı yorumu gündeme gelmektedir. Bu durumda ise defterin Abdurrahman Efendi'ye veya Bostan Efendi'ye ait olma ihtimali doğmaktadır. Abdurrahman Efendi'nin 964/1557 Bostan Efendi'nin ise 958/1551 tarihinde Rumeli Kadıaskerliği'nden ayrıldığı ${ }^{40}$ düşünüldüğünde katalog tarihinin teftiş tarihinden en az 10 yıl sonrasını gösterdiği düşünülmelidir. Bu durumda katalog tarihinin evrakın temize çekildiği tarih olma ihtimali göz önüne alınmalıdır.

Nihayetinde defter hangi Kadıaskere ait olursa olsun ilmiye teşkilâtı açısından kıymetli bilgiler içermektedir. Bu bilgiler defter içerisinde şikâyet edenlere göre belli başlıklar altında incelenmiştir. Birinci başlıkta müderrislerin, ikinci başııta kadıların, üçüncü başlıkta henüz mansıba girmemiş mülâzım zümresinin davaları incelenmiş son kısımda ise müezzin, mütevelli, seyyid ve müteferrika zümresinin davaları kaydedilmiştir.

Metin tahlil edildikten sonra metnin sonuna "çeviri metin" eklenmiştir. $\mathrm{Bu}$ işlem gerçekleştirilirken mümkün olduğunca asıl metne sadık kalınmış, isimler günümüzde söylendiği şekilde ancak kelime sonlarındaki sessiz harfler yumuşatılmadan Ahmed, Mehmed gibi verilmiştir. Asıl metinde olmayan

37 IImiye Salnamesi (Osmanlı Ilmiye Teşkilâtı ve Şeyhülislamlar), nşr. Seyit Ali Kahraman-Ahmed Nezih Galitekin-Cevdet Dadaş (İstanbul: İşaret Yayınları, 1998), 326.

38 Selânikî Mustafa Efendi, Tarih-i Selânikî, nşr. Mehmet İpşirli (Ankara: TTK, 1999), 1: 52.

39 BOA, TS.MA.d, 5789/1, Vr. 003.

40 Atâyî, Hadâ'iku'l-Hakâ'ik, 469. 
noktalama işaretleri eklenmiş, ayrıca olub, olân geri, edib, görülmâsı, virilmâsı, eyledûği gibi kelimeler okuyuşu kolaylaştırması amacıyla günümüz kullanımına uygun olub, olan, geri, edib, görülmesi, verilmesi şeklinde ifade edilmiştir.

\section{MÜDERRISLERIN ŞIKÂYET KONULARI VE VERILEN CEVAPLAR}

İstanbul Efdalzâde Medresesi'nden 40 akçe ile ma'zul olan Mevlâna Şemseddin Efendi, medresenin vakfiyesine uyulmadığını, vakfiyede müderrisliğin kendisine şart kılındığı halde elinden alındığını, 42 aydır ma'zul olduğunu ve bu süre içerisinde istediği iki medresenin kendisine tevcih edilmeyip başkalarına verildiğini söylemektedir. Ancak ondan medrese vakfiyesinde bahsettiği durumu kanıtlaması istendiğinde, bunu gösteremediği ve diğer iki medreseye atanan kişilerin ise daha ehil kişiler olduğu cevaben belirtilmiştir.

Edirne Çukacı Hâcı Medresesi'nden ma'zul olan Mevlâna Hasan, 32 aydır ma'zul olduğunu belirtmekte istediği medresenin talep ettiği halde kendisine değil de 6 ay mülâzemeti olan Mevlânâ Alâeddin'e verilmesini şikâyet etmektedir. Verilen cevapta daha az mülâzemeti olmasına rağmen Alâeddin'in müderris olarak atanmasının hayatta olan vâkıfın şartı olduğu ifade edilmektedir. ${ }^{41}$

Gelibolu Saruca Paşa Medresesi'nden 48 aydır ma'zul olan Mevlânâ Şüca', istediği Sultan Murad Han Medresesi'nin kendisine değil Ahizâde'ye verilmesini şikâyete konu etmektedir. Ancak Ahizâde'nin imtihan sonucu ehil olduğunun anlaşıldığı ve bu sebepten İstanbul'a arz olunarak görev verildiği belirtilmiştir. ${ }^{42}$

Mevlânâ Carullah, İznikmid'de (İzmit) bir medreseden 20 akçe ile ma'zul olup 25 akçe ile İstanbul ve Edirne'de boşalan medreselere atanamamasını davaya konu etmektedir. Kadıaskeri kendi mülâzımlarını hak etmedikleri halde atamakla suçlamaktadır. Kadıasker verdiği cevapta ilmiye teşkilâtının kuralları gereği işlem yaptığını belirtmektedir. Kadıasker bu kurallar ile kenar medreselerinden ${ }^{43}$ ma'zul olanlara iç-il ${ }^{44}$ de terakki ile medrese verilemeyeceğini ve Anadolu medreselerinde görev alması dolayısıyla Rumeli'de bir medreseye atanamayacağını hatırlatmaktadır. Ayrıca müderris olarak atananların imtihan edilerek belirlendiğini dolayısıyla iç-il medreselerine atanmayı hak ettiklerini ifade etmektedir. ${ }^{45}$

\section{KADILARIN ŞIKKÂYET KONULARI VE VERILEN CEVAPLAR}

İstanköy kazasından 50 akçe ile ayrılmış olan Alaeddin, bazı kötü niyetli kişilerin şikâyetleri ile süresinin bitmesine iki ay kala azledildiğini 17 aydır ma'zul olduğunu

41 BOA, TS.MA.d, 5789/1, Vr. 001

42 BOA, TS.MA.d, 5789/1, Vr. 001

43 İç-il medreseleri dışındaki diğer medreseler.

44 İç-il medreseleri; İstanbul, Edirne ve Bursa şehirlerinde bulunan medreselere verilen isimdir. İçil medreselerinden mezun olmanın en önemli avantajı Sahn medreselerine atanma şansına sahip olmaları ve buradan 500 akçeli mevleviyet kadılıklarına ve Kadıaskerlik ile Şeyhülislamlık makamlarına ulaşma imkanı tanımasıdır.

45 BOA, TS.MA.d, 5789/1, Vr. 001. 
ifade etmekte ve talep ettiği Malkara ve Hayrabolu kazalarının kendisine tevcih edilmediğinden şikâyet etmektedir. Verilen cevapta, rûznâmede ${ }^{46}$ müddetinin bitmesine yakın bir zamanda şikâyet edildiği için görev süresinin bitmesinden 2 ay önce azledilmesinin arz edildiği kayıtlı denilmektedir. Dolayısı ile 2 ay önce azledilmesinin hukuki zemininin olduğu belirtilmektedir. İstediği kazâların ise kendi hakkı olmadığı, Malkara kazasının 70 akçe ile Hayrabolu kazasının ise 80 akçe ile başkasına tevcih kılındığı belirtilmiştir. ${ }^{47}$

Mevlânâ Hüsrev, 35 akçe ile Hurpeşte kadısı iken 40 akçe ile Usked? kazasına atanmıştır. Ancak sancak beyi ondan şikâyetçi olmuş, kazanın nizamsız ve boş olduğunu bildirdiği için kaza, 30 akçe ile başkasına verilmiştir. Kadı Hüsrev yapılan suçlamaları kabul etmekte, şikâyetçi olmadığını bildirmekte ancak müfettiş defterinde durumu bilinmeyenlere "mansıb yoktur" denildiği için halini bildirmeye geldiğini ifade etmektedir. ${ }^{48}$

Mevlânâ Muhyiddin, 10 yıl mülâzemeti olduğunu iç-il medresesine talip iken 35 akçe ile İpsala kazasına görevlendirildiğini belirterek davacı olmaktadır. Cevapta iç-il medresesine atanma hakkının olmadığı ve kenar medresesini de kabul etmediği yazılıdır. Semâniye müderrislerinden olan kardeşi Şemseddin, "kadılık verirseniz kabul eder" dediği için İstanbul'a sorularak kadılığa atandığı belirtilmiştir. Ayrıca gelen kararda eğer kabul etmez ise yeniden değerlendirilmesinin uygun görüldüğü belirtilmektedir. ${ }^{49}$

Rahoviçe kadısı Şüca', 14 aydır mülâzemette bulunduğunu, bu süre zarfında bazı kadılıkların boşaldığını ancak kendisine verilmediğini söylemektedir. Kendisine bu kadılıklara atanmayı talep edip etmediği sorulduğunda talep etmediğini ama mülâzemet ettiğini bildirmektedir. Verilen cevapta atanan kişilerin göreve daha layık kişiler olduğu ve ayrıca görevi talep ettikleri için onlara verildiği belirtilmiştir. ${ }^{50}$

Siroz Selçuk Hatun Medresesi'nde 20 akçe ile müderrislik yapmakta iken kendisine sorulmadan 30 akçe ile Köprülü kadılığına atanan Mevlânâ Sinan,

46 Rûznâme: Kadıasker tarafından tutulan, günlük kadı ve müderris atamalarını içeren defter.

47 Kazâların sınıflandırılması kazadaki hane sayısından yola çıkılarak kadının bir günlük yevmiyesi hesaplanmak sureti ile yapılmıştır. Kadıaskerin atama yaptığı kazaların derecelendirmesi 30, 40, 45, 50, 60, 70, 80, 100, 130, $150,200,300,400,450$ ve 499 akçe şeklinde yapılmaktadır. Bu derecelerden birinden ayrılan kadının bir sonraki görevinin normal silsile takip edildiğinde bir üst derece olması beklenmektedir.

48 BOA, TS.MA.d, 5789/1, Vr. 001.

49 BOA, TS.MA.d, 5789/1, Vr. 001.

50 Buradan kadıların göreve atanmak için bizzat başvuruda bulunmuş olmaları gerektiği anlaşılmaktadır. Furat, müderris atamalarında taliplilerin kendilerinin mi başvuruda bulundukları yoksa Kadıaskerler tarafından mı tespit edildikleri konusunun açık olmadığını ama adayların da başvurmalarının muhtemel olduğunu belirtmektedir (Ayşe Zişan Furat, "Fetih Sonrası Osmanlı Eğitim Anlayışının Şekillenişi: Klasik Dönem Müderrislik İmtihanları”, Osmanlı'da Ilim ve Fikir Dünyası (İstanbul'un Fethinden Süleymaniye Medreselerinin Kuruluşuna Kadar), ed. Ömer Mahir Alper-Mustakim Arıcı (İstanbul: Klasik Yayınları, 2015), 21). Ancak yukarıdaki ifadeden başvuruda bulunması gerektiği açıkça ifade edilmektedir. Biz bunun kadı ve müderris atamaları için de geçerli olduğunu düşünmekteyiz. 
Kadıasker'in kendi mülâzımlardan bir cahili Selçuk Hatun Medresesi'ne görevlendirdiğini, kendisinin ise korkusundan ses çıkaramadığını ifade etmektedir. Sonrasında bir medreseye atanmak şartı ile kazadan feragat (istifa) ettiğini, "düştüğü (boşaldığı) vakit verelim" deyip kendisini görevden aldığını ve boşta kaldığı için şikâyetçi olduğunu belirtmektedir. Verilen cevapta Kadıasker, kayınbabasının Sinan'ın kazayı istediğini söylediğini bunun üzerine kendi mülâzımlarından 34 ay mülâzemeti olan Ahmed'e Selçuk Hatun Medresesi'ni verdiğini ve Sinan'ın da bu durumu kabul ettiğini söylemektedir. 8 ay sonra geldiğinde medreseye atanmak istediğini, feragat edip imtihan olduğunu ve risale verdiğini ancak ona uygun bir medrese olmadığından beklemeye başladığını dolayısıyla bir haksızlık olmadığını iddia etmektedir. ${ }^{51}$

Mevlânâ İsa, 40 akçe ile Priştine kazasından müddetini tamamlamadan azledildiğini, 48 aydır mülâzemette olduğunu, bunun bir yılının mülâzemet müddeti olarak kabul edilebileceğini, diğer 3 yılı için haksızlığa uğradığını ve bu süre için kazanın gelirini istediğini belirtmektedir. Kadıasker, kadılık mahsulünü talep etmesinin şer'i olmadığını ve kendisinin bilgisizliğine delil olduğunu söylemektedir. Atama kayıtlarının tutulduğu rûznâmede Mevlânâ İsa hakkında şikâyet olduğu ve kanuna aykırı hükümlerinin bulunması sebebiyle azledildiği kaydedilmektedir. Bu delillerde hâlâ şüphe bulunmadığı, medreseye atanmak istediğini ancak mülâzemette bulunmasında da eksiklik olduğu bu yüzden atanmadığı belirtilmekte ayrıca teftiş meclisinde bir yıl istifasını itiraf ettiği zikredilmektedir. ${ }^{52}$

30 Akçe ile Ebulmarina kazasından ma'zul olan Abdullah, kadısı olduğu kale dizdarının ona iftira ettiğini ve onun isnadı üzere haksız yere azledildiğini, onun isnatlarının doğru olmadığına dair elinde temessukler bulunduğunu belirtmekte veşahit göstermektedir. Kadıasker cevabında, kale dizdarının onun hakkında"gece gündüz fısk üzere olup bazı kimseleri yalandan yere dava ederek cezalandırdığını ve halkın nefretini kazandığını" söylediğini ifade etmektedir. Şahitlerin de isnat olunan suçların bazılarını kabul ettiğini bazılarını da kabul etmediğini, bu sebeple dava sonuçlanana kadar yerine başkasının görevlendirildiğini belirtmektedir. ${ }^{53}$

Hurpeşte kazasından ma'zul olan Mevlânâ Şemseddin, 18 aydır ma'zul olduğunu, birçok kere talep ettiği mansıpların ona değil başkasına verildiğini söyleyerek şikâyetçi olmaktadır. Kadıasker ise atanan kişilerin hem zaman olarak hem de ehil olma noktasında Mevlânâ Şemseddin'den daha layık olduklarını belirtmektedir. ${ }^{54}$

51 Furat, medreselere atanmada birden fazla talipli olması durumunda talipliler arasından seçim yapmak üzere imtihan yapıldığını belirtmekte, tek bir talibin yeteneklerini ve meziyetlerini ispat için yapılan bir imtihan kaydına rastlanılmaması dolayısıyla imtihanın talipliler arasından başarılı olanı belirlemek amacıyla yapıldığını düşünülmesi gerektiğini belirtmektedir (Furat, "Fetih Sonrası Osmanlı Eğitim Anlayışının Şekillenişi”, 20). Ancak buradaki ifadelerden henüz atanılacak medrese belli olmadan, herhangi bir medreseye atanmak için de bir sınav yapıldığı bilgisine ulaşılabilmektedir.

52 BOA, TS.MA.d, 5789/1, Vr. 001

53 BOA, TS.MA.d, 5789/1, Vr. 002

54 BOA, TS.MA.d, 5789/1, Vr. 002. 
Girebene kazasından 12 aydır ma'zul olan Mevlânâ Nasuh, "bir buçuk yılım var iken müddeti doldu diye beni görevden aldılar" demektedir. Verilen cevapta altı aylık cezanın kürekçi ${ }^{55}$ ve avarız ${ }^{56}$ vergilerinin gecikmesinden dolayı ${ }^{57}$ verildiği halde kaza isimleri ile tarihlerin bulunduğu, özet rûznâmede sehven bir yıl önce yazıldığı ve müddeti tamam oldu diye azledildiği kaydedilmiştir. Buradan anlaşıldığına göre bir buçuk yıl değil ama 12 ay önceden yanlışlıkla azledildiği kabul edilmiştir. ${ }^{58}$

Karadağ kazasından 19 aydır ma'zul olan Mevlânâ Mukarreb, istediği kazâlara atanamadığı için şikâyetçi olmaktadır. Başvurduğu ancak kabul edilmediği kazalara kadıaskerin kendi mülâzımını, tezkirecisini ve mücrim bir kişiyi atadığını belirtmektedir. Ayrıca her atamada imtihan istediğini ancak imtihan dahi edilmediğini eklemektedir. Kadıasker tarafından Mevlânâ Mukarrebin iddialarının her birine ayrı ayrı cevaplar verilerek iddialarının asılsız olduğu ispatlanmaya çalışılmıştır. Böğürdelen kazasına atanmak istediğinde onun 6 ay mülâzemetinin, atananların ise 18 ve 20 şer ay mülâzemetleri olduğu, davacı Mukarrebin 12 ay mülâzemeti olduğunda atanmayı istediği zaman ise atanan kişinin tezkireci olduğu ve 15 ay mülâzemetinden başka sefer-i hümayuna katıldığı belirtilmiştir. Pınarhisarı kazasına atamada, onun 9 ay mülâzemetine karşın atanan kişinin cürmünün bilinmemesinin yanı sıra defterdarların padişah hizmetinde çalışkan dedikleri sebebiyle atandığı ve atanan tüm kadıların asıl mülâzım, "mevâli-i 'ızâm"dan mülâzım, olduğu belirtilmiş ancak Mukarreb'in Mevlânâ Hidâyet'in umumdan mülâzımı olduğu belirtmiştir. Limni kazasına atanan kadı, Mukarreb'in 20 akçeden ma'zul olmasına karşın, 25 akçeden ma'zul ve daha çok ilim ehli olduğu kayıt altına alınmıştır. İmtihan yapılmama nedeni ise atanan kişilerin daha ehil olduğuna dair hiçbir şüphenin bulunmaması gösterilmiştir. ${ }^{59}$

Mevlânâ Sinan, rûznâmede "görev süresinin bitmesine 2 ay kala feragat etti" diye azledilmesinden şikâyetçi olmuştur. Kadıasker azledilmesine gerekçe olarak görev süresinin bitmesine 40 günü kaldığı halde görev yerinde değil de İstanbul'da olmasını göstermiştir. Kırk günde görev yerinde olmasına imkân olmadığı sebebiyle feragat etmiş sayıldığı bildirilmiştir. ${ }^{60}$

55 Kürek ve kürekçi vergisi, donanma ihtiyaç duyduğu zaman 50 hane başına bir kürekçi olmak üzere çıkarılıyordu. Kürekçi ihtiyacı giderildiğinde yerine bedel olarak para da alınabiliyordu (Halil Sahillioğlu, "Avârız", Türkiye Diyanet Vakfı İlâm Ansiklopedisi (Ankara: TDV Yayınları, 1991), 4: 108; Feridun Emecen, "Bedel", Türkiye Diyanet Vakfı İslâm Ansiklopedisi (Ankara:TDV Yayınları, 1992), 4: 301; Mehmet Akif Aydın, "Osmanlı Ceza Hukuku”, Türkiye Diyanet Vakfı İsâm Ansiklopedisi (Istanbul: TDV Yayınları, 1993), 7: 479).

56 Mali bir terim olarak avarız, 4 ile 50 haneden alınan, düzenli olmayan örfi bir vergidir. Genellikle savaş zamanlarında intiyaç duyulduğu zamanda toplanmıştır. Ancak sürekli yapılan savaşlar bu vergiyi de normal vergiler arasında dahil etmiştir (Sahillioğlu, "Avârız", 108).

57 Avarız vergilerinin toplanması, sefer zamanında gerekli okçu, kürekçi, beygir temini ve bunların nakli için iskelede at gemilerinin toplanması kadıların görevleri arasındadır (illber Ortaylı , "Osmanlı Devleti'nde Kadı", Türkiye Diyanet Vakfı İlâm Ansiklopedisi (Ankara: TDV Yayınları, 2002), 24: 72). Bunlarda aksama olması durumunda çeşitli yaptırımlar söz konusu olduğu gibi vergi toplamadaki başarı taltif sebebidir.

58 BOA, TS.MA.d, 5789/1, Vr. 002.

59 BOA, TS.MA.d, 5789/1, Vr. 002.

60 BOA, TS.MA.d, 5789/1, Vr. 002. 
Aydos kazasından ma'zul Mevlânâ Sinan, Kadıaskerin menâsıb tevzî'inde adaletli olmadığından şikâyet etmektedir. Bu durumu örnekleri ile açıklamaktadır. Ona göre Yazıcızâde Mehmed 25 akçeden 50 akçe ile Zihne kazasına, Kara Recep 35 akçelik kazadan 100 akçe ile Budin kazasına, Behram isimli kadı ise 30 akçelik kazadan 60 akçelik kazaya atanmıştır. ${ }^{61}$ Mevlânâ Sinan kendisinin Şeyhülislâm Efendi'nin ${ }^{62}$ Kadıaskerliği döneminde tezkirecisi olduğunu ve Çorlu kazasına atanmayı istediğini ancak kadıaskerin kendi tezkirecisi, 30 akçe ile Silivri kazasından ma'zul Sinan'ı tercih ettiğini belirtmektedir. Yine İvranya kazası boşaldığında atanmayı talep ettiğiniancakmansıpalamadığınışikâyetetmektedir. Kadıasker verdiği cevabında ilmiye teşkilâtının işleyişi hakkında önemli hususları açıklamaktadır. Burada kimlere hangi vesileler ile terakki verileceği anlatıldıktan sonra şikâyete konu olan tüm atamalar hakkında tek tek tafsilatlı bilgiler verilmiştir. Yazıcızâde'nin Müfti Efendi'den mülâzım olduğunu, üstün vasıfta olduğu için terakki aldığını; Kara Recep'in Mevlâna Kemal Paşazâde'den mülâzım olduğunu, asla kendi mülâzımı olmadığını, 35 akçeden değil 50 akçe ile Drama kadılığından atandığını, Eskaradin? kazasının uç olup kimse gitmediği için 60 akçe görevlendirildiğini, oradan sonra 70 akçe ile Malkara kazasına sonra 80 akçe ile Hayrabolu kazasına, buradan da Budin kazasına kimsenin gitmemesi üzerine, onun terakki almaya hakkı olması ve uç yerlere devletin hükmünün gitmesi için 100 akçe ile atandığı belirtilmiştir. Behram kadı ise sâbık İstanbul kadısı Mevlânâ Hasan'ın mülâzımı olup terakki almayı hak etmiş bir kişi olduğu belirtilmiştir.

Şikâyete konu bir diğer atamada Seluri kazasından ma'zul olan Sinan, Defter-i Hakanî'de 35 akçe ile kayıtlı bulunan Çorlu kazasına atanmış ama şikâyetçi Sinan orayı 40 akçe ile istemiştir. İvranya kazası da yine 35 akçelik kaza olarak kayıtlı olduğu için arz olunmuştur. Şikâyetçi Sinan'ın ise yeterliliğine dair şüphe duyulmaktadır. Görev yaptığı her yerde şikâyetçileri eksik olmamıştır. Hatta teftiş meclisinde birçok kimse onun düğün edip uygunsuz şarkılar çaldırdığını haber etmiştir. Bu yüzden terakki alamamıştır. Kadıasker verdiği terakkilerin rûznâmede örnekleri olduğunu ve terakki verilmesi için gerekli şartların sağlandığını belirtmektedir. Çoğu medreselere ise vâkıfın şartı ile müderris tayin ettiğini belirtmektedir. Ancak bu gibi tafsilatın rûznâmelerde yazılmasının gelenek olmadığını bildirmekte, terakki gerekçeleri için verilen battal arzlara bakılması gerektiğini, bunların ise müfettiş efendiye gösterilip teslim edildiğini kaydetmektedir. Kanun dışı bir atama yapılmadığını hatta vâkıf şartıyla mansıp alanların atamalarının ekine ilmiye tarîkine girmemeleri gerektiğini yazdığını eklemiştir. ${ }^{63}$

61 Normal şartlarda silsile takip edilmeli ve 35 akçelik kazadan 40 akçelik kazaya, 30 akçelik kazadan 35-40 akçelik kazaya, 25 akçelik kazadan ise 30 akçelik kazaya atama olması beklenmektedir.

62 Ebussuud Efendi olmalıdır.

63 BOA, TS.MA.d, 5789/1, Vr. 002. 


\section{MANSIBA GIRMEMIŞ MÜLÂZIM ZÜMRESININ ŞIKKÂYET KONULARI VE VERILEN CEVAPLAR}

Mevlânâ Muhyiddin, 4 yıldır mülâzemette beklemekte olup Kadri Efendi'den nevbette ${ }^{64}$ mülâzım olmuştur. İç-il medreselerinden birçoğu boşaldığı halde kendisine verilmediğini, Kadıaskerin mansıpları kendi mülâzımlarına ve başkalarına verdiğini, kendisinin mağdur edildiğini bildirmektedir. Cevapta İç-il medreseleri tevcih kılınırken imtihan yapıldığını ancak Muhyidddin Efendi'nin asla imtihana gelmediği, sadece kadıaskerin azlinden bir ay kadar önce bir risale getirdiği belirtilmiş, bu risalenin de onun tarafından yazıldığının anlaşılamadığı bildirilmiştir.65

Vefat eden Mısır Kadısı Abdulkadir'in danişmentleri mülâzım olduklarını, kendilerine "karışıklık çıkarmamaları halinde mülâzım defterine kayıt olacakları" söylendiğini, sonra ise defterden isimlerinin silinerek "padişah size imtihan emreyledi" diye cevap verildiğini söylemektedirler. Cevapta Padişahın sefer-i hümâyûnda iken hepsinin mülâzım olmasını emrettiğini, seferden dönülünce tayin olsunlar dediğini, ancak onların anlaşmazlığı son bulmayıp uzadığı ifade edilmiştir. Sonrasında kendileri gelip anlaştıklarını bildirmişler, bu durum Anadolu Kadıaskeri'ne danışılmak istenmiştir. Tezkireci ise onların isimlerini yanlışlıkla mülâzım defterine yazarak temize çekmek için mücellide göndermiş, bu arada padişah ise imtihana tabi tutulmalarını istemiştir. Tezkirecinin hatası sebebiyle mülâzım defterine yazılan isimler mülâzım defterinden bu sebeple çıkarılmıştır.

İstanbul kadılığından ma'zul olup Semaniye medreselerinde müderris iken vefat eden Hasan Çelebi'nin, Edirne kadılığından emekli Mevlânâ Çelebi'nin ve Bağdat kadısı iken ölen Mevlânâ Kemal'in danişmentleri, zamana bakılmadan istihkakları ile 15 kişinin mülâzım alınıp, kalanlarının nevbet mülâzımı alınmaları doğrultusunda ferman verildiğini belirtmişlerdir. Kalanlar ise mülâzım alındığı zamanda tekrar isbata muhtaç olmamak için isimlerinin kayıt altına alınmasını istemişler ve kabul görülmüştür. Sonrasında ise Hasan Çelebi'nin mülâzımları yukarıda bahsedilen karara rağmen isimlerinin yazılmamış olmasını şikayet etmektedir. Verilen cevapta, şikâyet edenlerin Anadolu kadıaskeri ile yapılan imtihanda başarı gösteremeyenler oldukları bildirilmektedir.

\section{DiĞER KONULAR HAKKINDA DAVALAR}

Kara Hasan isimli biri Canbaz Mustafa evkafında mütevelli olduğunu ve vakfiyede tedris ücreti olarak 13 akçe, talebe için 6 akçe öngörüldüğünü, vakfın

64 Nevbet: Belirli sürelerle ilmiye mesleğindeki kişilerin mülâzım alınması anlamını taşımaktadır. Her yedi yılda bir nevbet ilan edilmekle birlikte, bir zafer kazanılması, sefer-i hümâyûn, cülus gibi sebeplerle de nevbet ilan edilmiştir. (Uzunçarşılı, Osmanlı Devleti'nin IIImiye Teşkilâtı, 55; Beyazıt, Osmanlı IIlmiye Mesleğinde İstihdam, 72.)

65 İmtihan risalelerinin imtihan esnasında mı yazıldıkları yoksa daha sonra mı derlenip toparlandıkları tam belli değildir. (Furat, "Fetih Sonrası Osmanlı Eğitim Anlayışının Şekillenişi", 24.) Buradaki ifadeden anlaşıldığı üzere risaleler, verilen bir konu üzere atama öncesinde serbest bir şekilde de yazılmaktadır. Ancak risalenin ilgili kişi tarafından yazıldığının kanıtlanması için belli bir yerde gözetim altında yazmış olması önemlidir. 
geliri müsait olduğunda ise ücretlerin 20 ile 10 akçe olarak uygulanmasının şart koşulduğunu ifade etmektedir. Buna dayanarak gelir müsait olduğunda 20 akçe verildiğini belirtmektedir. Gelir azaldığında ise İstanbul kadısı merhum Mevlânâ Saidi Çelebi'nin vakfın asli malından vermesini sonra vakfın mahsulünden alabileceğini gösteren hüccet ${ }^{66}$ verdiğini, buna dayanarak müderrise yine 20 akçe verildiğini belirtmektedir. Böylece vakfın aslî malından 34 bin akçe alınmıştır. Buhuri isimli bir kadı müfettiş olarak gelince "vâkıfın şartına aykırı iş yapılmış" diyerek "verdiğin yerden al" diye bahsedilen miktarı Hasan'a ödetmiştir. Hasan bu durumu Dîvân'a götürmüş Anadolu Kadıaskeri Mevlânâ Sinan Çelebi müfettiş tayin olunmuş ve o merhamet ederek, "kendine değil, vakfa sarf eylediğinden mütevellilik yine ona verilsin ve harcadığı meblağı vakfın fazlalığından alsın" diye işaret buyurmuş ama "arz benim uhdemde değildir, Rumeli Kadıaskeri'nindir" demiştir. Kara Hasan, Rumeli kadıaskerinin ise arz etmediğini ve kendisine haksızlık yapıldığını ifade etmektedir. Verilen cevapta Rumeli Kadıaskeri tüm olanların kendi bilgisi dışında olduğunu vakıf malında 34 bin akçe zarar bulunduğunu, ma'zul olan mütevellinin hali bilinmeden İstanbul'a arz edemem diye zamanında karar verdiğini bildirmiştir.

Teftiş meclisinde bulunmayıp başvurusu olduğu anlaşılan Hayreddin, Grebene kazasından 25 akçe ile ma'zuldur. 35 akçe ile Lofça kazası sadaka buyrulduğunda Müfettiş Mevlânâ Şemseddin, Hayreddin için "Anadolu Kadıaskeri mahiyetinde olması gereken birisidir" demiş ve Anadolu Kadıaskeri ile konuşulduğunda o da bunu doğrulamıştır. Bu sebeple Anadolu'ya geçmesi gerektiğinden yeri başkasına verilmiştir. Ancak kendisi rûznâmede "feragat etti" diye yazıldığını ancak feragat etmediğini söylemiş ve mansıp istemiştir. Rûznâmeye bakıldığında tezkirecinin Anadolu Kadıaskerine sorulma isteğini yanlış olarak feragat hükmünde anladığı ve öyle yazdığı anlaşılmıştır. Dolayısıyla isteği yersizdir. Hatta Anadolu Kadıaskeri'ne başvurması gerekmektedir.

Kadıasker, Nâkibü'l-eşrâf hakkında kanuna aykırı dava yaptığı, ona hürmet etmediği ve mahkemeye çağırdığı gerekçesi ile şikâyet edilmektedir. Ancak Kadıasker bunu kabul etmemekte, kendisinin Seyyitlere uygun olmayan bir davranış yapmadığını söylemekte ve mahkemeye çağırmak için kimseyi göndermediğine dair yemin etmekte, bunların iftira olduğunu bildirmektedir.

Üsküb'lü Ömer isimli birisi bazı kişilerin kendisinden 30 bin akçe dava ettiğini bunun isbatı için yalancı şahitler getirdiklerini ancak kadıaskerin onları araştırmadan, kendisini nice zaman hapsettirdiğini ve türlü eziyetler yaptığını belirterek şikâyet etmektedir. Cevapta şikâyetlerin şer'i olarak değerlendirildiği ve ona göre karar verildiği belirtilerek tekrar mahkeme talep ettiğinde "görülmemiş

66 Hüccet: Bir hükmün doğruluğunu kanıtlamak amacıyla ileri sürülen delil; (Yusuf Şevki Yavuz, "Hüccet”, Türkiye Diyanet Vakfı İslâm Ansiklopedisi (Ankara: TDV Yayınları, 1998), 18: 445) kadı tarafından hukuki bir hadiseye dair düzenlenen vesika (M. Zeki Pakalın, “Hüccet”, Osmanlı Tarih Deyimleri ve Terimleri Sözlüğü (İstanbul: Milli Eğitim Bakanlığı Yayınları, 1983), 1: 865). 
kanıtların var ise ona göre hükm verilsin" denilmiş ancak yeniden dava edilmesini gerekecek belgeler sunulmamış ve "kanuna aykırı bir uygulama görülmemiştir" diye belirtilmiştir.

Bundan başka da nice kimseler gelerek kanun bilmemekten kaynaklanan itirazlar ettikleri bunların dava olarak görülmeleri bile gerekmezken itiraz edilmediği ve hepsinin şer'i olarak görüldüğü eklenmiştir.

\section{TEFTiŞ DEFTERINDE ILMIYE TEŞKILÂTININ IŞLEYişiNE AiT UYGULAMALAR}

İlmiye teşkilâtının işleyişine ait uygulamaların bir kısmını kânûnnâmelerden, rûznâmçelerden, tarîk defterlerinden ve diğer atama kayıtlarından edinmek mümkündür. Ancak sistem içerisinde aksayan veya şikâyete konu olan uygulamaları tespit edebilmek için teftiş defterleri ayrı bir önemi haizdir. Şikâyet defterleri her ne kadar şikâyet ve bunlara verilen cevaplar açısından zengin bilgiler ihtiva etse de özellikle şikâyete konu durumların ifadesi esnasında ve bunlara verilen cevaplarda cârî olan sistemi açıklayan önemli bilgiler de içermektedirler. Bu açıdan incelenen defter dikkate alındığında ilmiye teşkilâtı hakkında aşağıdaki uygulamaların yürürlükte olduğu anlaşılmaktadır:

- Kânûn-ı kadîm ile kadı ve müderrislerin terakki alarak normal silsileden hızlı ilerlemeleri mümkündür. Ancak ilmiye kademeleri arasında hızlı ilerlemek için bazı durumlar şart koşulmuştur. Bu şartlar şu şekilde belirtilmiştir: Padişahın lütfuna nail olma, mevâli-i 'ızâmdan mülâzım olma, çalışkan ve ilim ehli olma, mehayif teftişinde görev alma, defterdarın yanında müfettiş olarak çalışma, şehzade şefaati, görev yerleri başka bir iş için lazım olup görevi elinden alınması durumunda, sefer-i hümâyûna katılma, uç bölgesinde olan veya kimsenin tercih etmediği kazalarda görev alma, hakkında şikâyet gelmeyip halkı memnun etme gibi durumlar terakki elde edilebilecek hususlar olarak ifade edilmiştir.

- Medreseye müderris tayinlerinde vâkıfın şartları belirleyicidir. Ancak bu şekilde görev alan müderrislerin ilmiye tarîkine girmemeleri için gerekli önlemler alınmış, bu müderrisler silsile dışında tutulmuştur.

- Kadılıktan medreseye atanmada medreseye atanmak istenen kişi tek kişi bile olsa sınava tabi tutulmaktadır.

- Aynı özelliklere sahip adayların bir medreseye talipli olmaları durumunda Kadıasker tarafından imtihan yapıldığı ve risale yazmaları istendiği görülmektedir.

- Atamaların tamamı İstanbul'a arz edilmektedir. Mevleviyet derecesine kadar kadı atamaları ile 40 akçeye kadar müderris atamaları Kadıasker yetkisi dâhilindedir. Ancak bu atamaların resmî geçerlilik kazanabilmesi için padişah onayından geçmesi gerekmektedir. 
- Kenar medreselerinden ma'zul olanlara iç-il de terakki ile medrese verilmemektedir. İç-il medreselerinde görev yapmak ilmiye tarîkinde önemli avantaj sağladığı için buralarda görev yapmanın şartları daha ağır olmuş, kenar medreselerinde görevli müderrisler iç-il medreselerinde görev yapmak istediklerinde ayrıca sınava tabi tutulmuşlardır.

- Kadılık görevinden sonra müderrislik görevine atanmak isteyenler tekraren imtihana tabi tutulmaktadır.

- Bir mansıba atanmak için mülâzemette beklemek ve boşalan görevleri takip ederek başvurmak gerekmektedir. Sadece mülâzemette bekleyerek hak kazanmak mümkün değildir. Hem mülâzemette olmak hem de boşalan mansıbı takip ederek başvurmak gerekmektedir.

- IIlmiye mensupları hakkında şikâyet gelmesi üzerine soruşturma sonuçlanana kadar görevden el çektirme yapılabilmektedir.

- Anadolu ve Rumeli Kadıaskerliği'nin hangisinde görev yapılıyorsa göreve orada devam etmek gerekmekte, farklı kadıaskerlik bölgesine atama tespit edildiğinde görev sonlandırılmaktadır.

- Atamalarda dereceler arası sıralamaya dikkat edilmektedir. Şikâyetlerin önemli bir kısmını sıralamaya uyulmadığı iddiası oluşturmaktadır.

- Sancak beyi, kadıların görev yapmamasından şikâyetçi olabilmekte ve Kadıaskere başvurarak görevden aldırabilmektedir.

- Kürekçi ve avarız vergilerinin geciktirilmesi görev süresinin kısaltılması cezasına sebep olmaktadır.

- IIlmiye teşkilâtına ilişkin kayıtlar tarih ve isimlerin bulunduğu özet rûznâme ile bir de detaylı rûznâmeye kaydedilmektedir. Ancak atamaya ilişkin detaylar rûznâmelerde bulunmamaktadır. Atamaların detayları arz edildiği battal arzlar içindedir.

- Görev süreleri rûznâmelere zaman zaman yanlış kaydedilmekte ve bu yüzden mağduriyetler yaşanmaktadır.

- Mevâlî-i 'ızâmdan mülâzım olanlar asıl mülâzım olarak değerlendirilmekte, umumdan mülâzım olanlar ise ikinci derece önemli kabul edilmektedir.

- Bir kazaya veya medreseye başvuran kişilerin ehil olmaları hususunda kesin kanaat varsa sınav yapılmayabilmektedir.

- Görev yerinden uzun süre ayrılmak istifa olarak değerlendirilmektedir.

- Hakkında şikâyet olması terakkiye engel bir durumdur.

- Vefat eden mevâlî danişmendleri sınava tabi tutulmuş, geçemeyenler umumdan mülâzım için bekletilmiştir.

- Şikâyete konu olan hususlar aşağıdaki gibi gruplanmıştır: 
- Vâkıfların şartlarına uyulmaması

- Hak etmeyen kişilere mansıpların verilmesi

- Mansıp verilirken mülâzemet süresine dikkat edilmemesi

- Kadıaskerlerin kendi mülâzımlarını tercih etmesi

- Kadıaskerlerin kendi tezkirecilerini tercih etmesi

- Düşmanlarının şikâyetleri üzerine azledilme

- Iftira ile azledildiğini iddia etme

- Görevden alındığı için mahsul-ı kaza isteme

- İmtihan ile atanma istenildiği halde yapılmaması

- Hak ettiği halde terakki alamama

- Mülâzım defterinde isimleri yazılı olduğu halde atanamama

- Mülâzemet defterine isimlerinin yazılmasının unutulması

- Diğer müfettişlerin raporlarına itiraz

- Yalancı şahitlerin yeterince araştırılmaması.

\section{SONUÇ}

Herhangi bir kurumun işleyişini ve bu işleyiş esnasındaki sıkıntıların neler olduğunu tespit edebilmek için ilgili kurum hakkında gelen şikâyetlerin ve bu şikâyetler sonucu yapılan tahkikatları içeren kayıtların incelenmesi önem arz etmektedir. Bu araştırmada da ilmiye teşkilâtının en önemli üyelerinden olan Kadıasker hakkında yapılan bir tahkikat ele alınmış ve sistemin işleyiş̧ine yönelik önemli bilgilere ulaşılmıştır.

Teftiş defteri içerisinde defterin ait olduğu tarihe, kişiye ve makama ait kesin hükümler bulunmamaktadır. Ancak yapılan incelemeler sonucunda defterin XVI. asrın üçüncü çeyreğine ait olduğu, Rumeli kadıaskeri hakkında yapılan bir teftişin kayıtlarını içerdiği ve kuvvetle muhtemel olarak Rumeli Kadıaskerlerinden Abdurrahman Efendi, Bostan Efendi veya Hâmid Efendi'den birine ait olduğu anlaşılmıştır.

Araştırma, ilmiye teşkilâtının işleyişi ve şikâyete konu olan hususlar hakkında önemli sonuçlara ulaşmıştır. Araştırmada kadı, müderris ve mülâzım zümresinin Kadıaskerin uygulamalarından şikâyetleri detaylı bir şekilde verilmiştir. Buna göre kadı ve müderrislerin şikâyetlerinin en önemli kısmını haksız olduğuna inandıkları atamalar teşkil etmektedir. Bu iddialar haksız bir şekilde görevden alınma, hak etmeyen bir kişinin göreve atanmasını ele alabildiği gibi yersiz terakkileri de konu edinmiştir. Atamalarda sınav yapılmadığı veya yapılsa bile sonucuna riayet edilmediği belirtilmiştir. Yine mülâzım zümresinde olanlar da haksız olarak mülâzım defterine kaydolamadıklarından veya isimlerinin bu defterden silinmesinden yakınmaktadırlar. 
Kadıaskerin verdiği cevaplar incelendiğinde şikâyete konu olan uygulamaların hepsinin gerekçesinin detaylı olarak açıklandığı görülmektedir. Gerekçelerin büyük kısmı somut delillere veya ilmiye teşkilatına ait mevcut kurallara dayanmaktadır. Çok az atamada kadıaskerin somut olmayan delillere dayandığı ve atanan kişinin daha ehil olduğunu belirttiği görülmüştür. Bu durumda sonuç olarak Kadıasker tarafından yapılan işlemlerin hukuka uygun olduğu sonucuna ulaşılabilecektir.

İlgili defterdeki kayıtlar şikâyete konu olan hususların neler olduğunu göstermenin yanında, özellikle Kadıaskerin şikâyetçilere verdiği cevaplarda, teşkilâtın işleyişine dair kıymetli bilgiler içermektedir. Bu cevaplarda ilmiye teşkilât mensuplarının terakki almaları için gereken şartlar ayrıntılı olarak ifade edilmiştir. Bir mansıba atanmada başvuranlar arasında öncelik sebebi olan durumlar açıkça belirtilmiş ve bu işlemlerin kânûn-ı kadîm icabı yapıldığı belirtilerek cârî olan kanun da açıklığa kavuşturulmuştur. Müderris atamalarında hangi şartlarda sınav yapıldığı ve kısıtlı da olsa sınavların çeşidine ilişkin bilgiler de sunulmuştur.

İlmiye teşkilâtı araştırmalarında henüz istenilen seviyede kullanılamayan teftiş defterlerinin araştırmalara daha fazla konu edilmesi teşkilâtın süreç içerisinde aksayan yönlerini daha net bir şekilde ortaya çıkarılabilecektir. Farklı dönemlere ait teftiş defterlerinin çalışmalara konu edilmesiyle süreç içerisinde şikâyete konu olan hususların gösterdikleri değişikliklerin tespit edilebileceği böylece ilmiye teşkilâtının süreç içerisindeki değişim ve dönüşümünün aydınlatılmasına önemli katkı sağlanacağı değerlendirilmektedir.

\section{Çeviri Metin}

Dergâh-ı gerdûn iktidârdan bu fakîr kesîrü't-taksîrin teftîşî için hükm-i şerîf ve el hubbu'l-imtisâl vârid olub imtisâla el-irâl'âlî meclis-i teftişe vârılıb teftîşe şurû' olundukda meclise gelenlerin kaziyyeleri yazılmağa mübâşeret olunub akvalları tamâm-ı ma'lûmumuz olub mukâbelede 'ale't-tâfsîl cevâblar verilib ve rûznâmeden yazdıkları maddelerin ve istiksâ tarîkî ile mesmû'ları olan maddelere dahî 'ale't-tâfsîl cevâb-ı şâfiyeler verilib lakin verilen cevâblar kema hüve'l-vaki yazıldı mı görelim dîdukde men' edib ve suret de taleb etdikde sûretde dahî vermedikleri ecilden meclise gelenlerin akvâlleri ve bu fakîrin mukâbelede vâkı' olan cevâbları 'ale't-tâfsîl yâzılmağa akdâm olundu. Ve rûznâmeden ve gayrıdan yazdıkları mâddelerin 'ale't-tâfsîl ihâtâsı mümkün olmamâğın cemı' vâkı' olan terakkîlerin cevâb-ı şâfiyesi dahî yâzılmaya akdâm olunub Âsitâne-i Sa'âdet'e irsâl olundu.

Âsitâne-i Sa'âdet'e mülâzemet îden tevâifden ve ğayrîden meclise gelenler bunlardır. 


\section{Zümre-i Müderrisînden Gelen Mevlânâ Şemseddin Ki}

Mahrûse-i İstanbul'da vâki 'olan merhûm Efdalzâde Medresesi'ne sâbıkâ yevmî kırk akçe ile müderris olup ma'zûl olmuştur. Pâdişâh-ı 'âlem-penâh hazretleri sefer-i hümâyûna buyurmazdan evvel medrese-i mezbûrenin vakfiyyesinde "medrese-i mezkûre bana meşrûtdur" dîdûgumde "fi'l-vâki' meşrût ise senden alınmâs" demişler idi. Ba'dehû müddetim tamâm olîcâk sefer-i hümâyunda âhara tevcîh edib 'arz edib sadaka buyurulmuş idi. Ve seferden geldiklerinden sonra medrese-i mezbûre evkâfının muhasebesini gördürüb 'adem-i musâ'adesi ma'lûmu olmuş iken rakabeye hükm etmeyib geri âhara tevcîh etdi. "Üç buçuk yıldır ma'zûlin matlabımda Kasım Pâşâ ve Çelebi ve Mustafa Pâşâ Medreseleri mahlûl olup bana tevcîh etmeyib aharlara verilmişdir" dîdûkde, cevâb: Vakfiyenin mezmûnû önümüzde şer'ân sâbit olmayûb ve vâkıf vakfiyede medrese şart etdiği kimesne mezbûr idûğî dahî şer'ân sübût bulmâdığı ecilden âhara tevcîh olundukdan sonra banâ meşrût" deyû taleb eyledûğünde fî nefsi'l-emr meşrût idûğı "şer'lle isbât et" dinledikde kabûl etmeyûb ellili medreseye tâlib olub ve evkâfın muhâsebesini ma'zûl kuzâtdan birine gör denildikde 'adem-i müsâ'adesi fehm olunub lakin mütevelli-i vakf muhasebesini Mürtezika rakabe olunmasını taleb etmeyib kadı Hanefi 'arz etmediği ecilden 'arz olunub rakabeye hükm olunmamışdır. Ve medrese tevcîh olunan müderris akçesi tamâma vâsıl olmâz denilib ne olur ise olsun deyû kabûl etmiş idi. Lakin mezbûr müderrisden suâl olundukda vech-i meşrûh üzere kabûlüne inkâr eyledi ve matlabında düşen Kasım Pâşâ ve Çelebi Medreseleri sadaka olunan kimesneler mezbûrdan ehak oldukları ecilden tevcîh olunmuştur. Ve Mustafa Pâşâ Medresesi bu hakîrin tevcîhi ile verildi. Lakin ol medreseye müderris olan dahî mezbûrdan ehakdır.

\section{Ve Mevlânâ Hasan}

Ki yirmi beş akçe ile mahrûse-i Edirne'de Cukacı Hâcı binâ eylediği medreseden ma'zûldur. "íki yıl sekiz aydır ma'zûlun. Matlabımda yine medrese-i mezbûre düştü. Yevmî yirmi beş akçe ile Dimetoka'da vâki' olan merhûm Mevlânâ Abdulvâni' Efendi Medresesi'nden ma'zul olub altı ay müddet-i mülâzemeti olan Mevlâna Alaaddin'e tevcîh eyledi" dîdûkde, cevâb: Medrese-i mezkûrenin vâkıfı hayy olub vakfiyesinden tevcîh-i medrese-i nefsine şartedib yevmî otuz akçe ile müşârun ileyh Alaaddin'e verilmesi murâdı idûgunu mahrûse-i mezbûre kadısı 'arz etdiğinden gayrı vâkıf-ı mezbûre husûs-ı mezbûru bizzât gelib bu fakire 'ilam eyledikde mâ hüve'l-vâki' Pâdişâh-ı 'âlem-penâha 'arz olundukda ol zamânda medrese-i mezbûreye yevmî yirmi akçe ile müderris olan Mevlânâ Muslihiddine yer görülmesı emr olunub, halle kâbil Dimetoka'da merhûm Oruç Pâşâ Medresesi bulunûb yirmi beş akçe ile sadaka buyurulûb, yeri vâkıf-ı mezbûr murâdı olan mezbûr Mevlâna Alaaddin'e yevmî otuz akçe ile ber mûcib-i şart-ı vâkıf sakada buyruldu. 


\section{Mevlânâ Şücâ'}

Ki yevmî yirmi beş akçe ile mahrûse-i Gelibolu'da merhûm Sârûca Pâşâ Medresesi'nden ma'zûldur. "Dört yıldır ki ma'zûlun matlabımda câmi'i 'atîk kurbunda vâki' olan merhûm Sultân Murâd Hân teğammedellahu bi'l-gufrân Medresesi düşûb bana tevcîh etmeyûb kasaba-i Seluri'de vâki' olan merhûm Pir Mehmed Pâşâ Medresesi'nden yevmî yirmi beş akçe ile müderris olub ma'zûl olan Ahîzâde'ye tevcîh eyledi" dîdikde, cevâb: Mezbûr Ahîzâde imtihân edib kemâl-i istihkâk ile müstehak bulub mezkûr Şüca' ile aslâ münâsebeti oldûğu ma'lûmumuz olduğu ecilden Âsitâne-i Sa'âdet'e 'arz olunub sadaka buyrulmuştur.

\section{Mevlânâ Cârullah}

Ki Anadolu vilâyetinden İznikmîd nâm kasabada vâki' olan medresede yevmî yirmi akçe ile müderris olub ma'zûl olmuştur. "Mahrûse-i İstanbul'da ve mahmiyye-i Edirne'de benim matlabında yevmî yirmi beş akçe yâzar medreseler düşdû. Bana virmeyûb Kîmini kendi mülâzımlarına ve kîmini gayrılara tevcîh eyledi" didûkde, cevâb: Mezkûrun medresesi vilâyet-i Anadolu'da olub ve kenar medreselerinden ma'zûl olanlara iç-il'de terakki ile medrese verilmek kânûn olmayub ve ol medrese verilen kimesnelerin istihkâkları mezbûrdan ziyâde idûğü imtihân tarîki ile bu fakîrin yanında ma'lûm olmuşdur.

\section{Ve Tâife-i Kuzâtdan Gelen Mevlânâ Alaaddin}

Ki İstanköy kazâsından yevmî elli akçe ile kadı olub ma'zûl olmuştur. "Bazı ehl-i garaz kimesneler şekvalarıyla müddetinden iki ay dahî var îken 'azl edib bir yıl beş aydır ma'zûlun. Matlabımda Malkara ve Hayrabolu kazâları düşdü. Bana tevcîh etmeyib âhara tevcîh ettin" didûkde, cevâb: Rûznâmeye nazar olundukda "müddet-i karîb olmağın 'azli buyuruldu" deyû mukayyed olub ve mezbûrdan şikâyetçiler dahî olub şikâyet edenler ehli garaz idûğü ma'lûmumuz olduğu ecilden, iki ayı dahî vâr iken 'arz olunub 'azli buyurulmuştur. Ve Malkara kazâsı yetmiş ile ve Hayrabolu seksen ile tevcîh olunub sadaka buyurulmuştur.

\section{Mevlânâ Hüsrev}

Ki kazâ-i Usked'den? yevmî kırk akçe ile ma'zûldur. Bundan esbak yevmî otuz beş akçe ile Hurpeşte Kadısı iken yevmî kırk akçe ile Ösek kazâsını tevcîh edib sadaka buyurulub Ösek'e vârûb üç ... hasıl olub cihet-i ma'îşetime hâsılı vefâ etmediğine sancak beyinden 'arz olmak üzere iken üç ... emr-i kazâ muhteldir deyû 'arz gelmeğin bî-hâsıl olduğu ecilden yevmî otuz akçe ile gayra sadaka olunmuş "hâliyen şikâyetim yok emma müfettiş defterinde hâlî ma'lûm olmayânlara mansıb yokdur dedikleri ecilden hâlimi i'lâma geldim" dedi. 


\section{Ve Mevlânâ Muhyiddin}

Ki sâbıkan Edirne kadısı iken fevt olan Mevlânâ Bedreddin'in oğludur. "On yıl mikdârı müddet mülâzemetim olub iç-il medresesine tâlib iken banâ otuz beş akçe ile İbsala kazâsını tevcîh etmişler" didûkde, cevâb: Iç̧-il medresesine istihkâkın yok idûgi ma'lûmumuz olub ve kenâr medresesini kabûl etmeyûb ve Semâniye Medreselerinin birine hâliyen müderris olan biraderi Mevlânâ Şemseddin "kazâ tevcîh idûn kabûl ider" deyû i'lâm etmeğin Âsitâne-i Sa'âdet'e 'arz olunub "kadılık virülsûn kabûl etmez ise yine görüle" deyû emr olunmuştur.

\section{Mevlânâ Şücâ'}

Ki on beş akçe ile Rahoviçe kazâsından ma'zûldur. "Bir yıl iki aydır ma'zûl mülâzemet iderîn zamân-ı mülâzemetimde bazı kadılıklar düşdü. Banâ vermeyûb âhara vîrdî deyûb matlabında düşen kadıkları taleb etti deyû sual olunub taleb etmedim amma mülâzemete vârır idim" didûkde, cevâb: Zikr olunân kadılıklar, verilenlerin mezbûrdan zâtâ ve zamâna istihkâkları ziyâde olduğundan gayri taleb etmişlerdir. Mezbûr taleb etmemeğin aharlara tevcîh olundu.

\section{Mevlânâ Sinân}

Ki yevmî otuz akçe ile Köprülü kazâsından ma'zûldur. Bundan esbak mahrûse-i Siroz'da vâki olan Selçuk Hâtûn Medresesi'ne yevmî yirmi akçe ile müderris iken râzî olmadı banâ yevmî otuz akçe ile Köprülü kazâsın tevcîh edib medrese-i mezbûre kendi mülâzımlarının bir câhiline tevcîh etti. Ben dahî havfımdam mezbûr kazâyı kabûl etdim. Ba'dehû 'azb? ve 'avârız getirmeğe geldiğimde yine yed-i âbid bir medrese tevcîh etmek şartı ile mezbûr kazâdan ferâğat etdüm idi. "Düşdûğü vakit virelûm" deyûb beni meccânen ma'zûl etdi" didükde, cevâb: Mezbûr Sinân'ın kâynatâlığı mezkûrun kazâya tevcîhini i'lâm etmeğin tevcîh olunub, sadaka buyurulûb medrese bu fakirden nevbette mülâzım olub iki yıl on ay müddet-i mülâzemeti olan Pîr Ahmed'e yevmî yirmi akçe ile sadaka buyurulûb merkûm Sinân dahî kazâ-i mezkûru kabûl edib sekiz ay tasarruf etdûkden sonra 'azb? götürdügünde yine medreseye tevcîh edib kazâ-i mezbûrdan ferâgat edib medrese içün imtihân olunub risâle virmişdi. Ol zamân hâline mülâyim medrese bulunmadığı sebebden verilmeyûb kazâ-i mezbûr âhara tevcîh olunub mezkûr Sinân'ın medreseye istihkâkı olduğu sebebden düşdüğü ve ... medrese tevcîh etmeğe müteveccih olmuş idik.

\section{Mevlânâ İsa}

Ki Piriştine kazâsından kırk akçe ile ma'zûldur. "Müddetim tamâm olmadan 'azl edib dört yıldır ki ma'zûl gezerin. Bir yılın müddet-i mülâzemete tut üç yıllık kazâ-i mahsûlin taleb ederîn" didûkde, cevâb: "Vech-i meşrûh üzerine kadılık mahsûlün taleb etdûğün şer'î değildir ve senin cehline dahî delîldir" dinildikde sonra rûznâmeye nazar olunub "hilâf-ı şer'î hüccetleri ve nakilleri olduğu 'arz olunub 'azl buyuruldu" deyû mukayyed bulunûb zikr olunân hüccetler ve nakiller 
bu fakirden taleb olundukda, ol zamân mezbûr kadının şikâyetçileri gelüb nice hilâf-ı şer'î imzâsıyla ve mührü ile hüccetlerîn ve nakillerîn getûrüb görüb ma'lûmumuz olub 'arz olunub 'azl buyurulmuştur. Hâliyen zikr olunân hüccetleri ve nakilleri ihzâra kâbiliyyet yokdur denildi. Ve pâdişâh-ı 'âlem penâh hazretleri sefer-i hümâyundan gelince asla mülâzemete gelmeyûb, ba'dehû birkaç gün gelûb, Edirne'ye bile vârmayûb mahrûse-i İstanbul'a gelindûğünde kazâya tâlib olmayûb, medreseye tâlib olub istihkâkı dahî ma'lûmumuz olmayûb, ba'dehû nîce zamân yine mülâzemete gelmemişdur. Dinledükden sonra mezbûr dahî meclis-i teftîşde bir yıl ferâğatın i'tirâf eyledü.

\section{D_05789_0001_00_002}

\section{Ve Masdarzâde Abdullah}

Ki otuz akçe ile Ebulmarina kazâsından ma'zûldur. "Kadısı olduğum kal’anın dizdârı banâ hilâf-ı vâki' bazı nesneler isnâd edib 'arz etmeğîn, nâmahall olmâğın "'azl buyuruldu" deyû rûznâmede mukayyed olmuş, isnâd itdûgü kaziyyeler hilâf-ı vâkı' idûgûne elimde temessuklerim dahî vârdır ve vilayet? yazan Mevlânâ Şis Efendi dahî isnâd olunân kaziyyleler, hilaf-ı vaki' idûğü ma'lûmları olub i'lâm itmişlerdir" didûkde, cevâb: Sa'âdetlû pâdişâh sefer-i hümâyûnda iken dizdârın 'arzı gelûb mezbûr, gece ve gündüz fısk üzere olub ve bazı kimesneleri mecruh edib ve meclisinde katl-i nefs olmağla halk müteneffir olub emr-i kazâda mürâca'at etmeyûb ahvâl-i kazâ muhtel idüğün 'ilam edib Âsitâne-i Sa'âdete 'arz olundukda memleketden ırâk yerde olmâğın tamâm-ı ma'lûm olunca memlekete ahvâli muhtel olmak ihtimâli ile 'arz olunub âhara verilmesi buyurulmuşdur. Ve mezbûr Şis kadı dahî "isnâd olunan kaziyyelerin bazılar vukû'unu ve bazılar adem-i vukû 'unu haber verdiler" deyû haber vermişdür ve elinde olan temessüklerine nazar olunub isnâd olunân kaziyyelerin da vâsından ibrâ hüccetleri imiş.

\section{Mevlânâ Şemseddin}

Ki yevmî otuz beş akçe ile Hurpeşte kazâsından ma'zûldür. Bir buçuk yıldır ki ma'zûldür. "Nice def'a matlabımda mansıblar düşdü banâ tevcîh etmeyûb aharlara tevcîh etmişdir" didûkde, cevâb: Cem'i verilenler zâtâ ve zamâna müstahaklardır. Kemâl-i istihkâkları olduğu ecilden tevcîh olunmuşdur.

\section{Ve Mevlânâ Nasuh}

Ki Girebene kazâsından ma'zûldur. "Müddetimden bir buçuk yılım daha var iken "müddeti tamâm olmuşdur deyû 'azl edib bir yıl mikdârî vârdır ki mülâzemet iderîn" didükde, cevâb: Altı ayı kürekçi ve 'avârız eclîçûn buyurulan halde dâhil olub ve kazâ-yı esâmîsi ve târihleri hıfzi için olan icmâl rûznâmede bir yıl sehven mukaddem yazılmış bûlunûb müddeti tamâm oldu deyû 'arz olunub 'azl buyurulmuşdur. Hâliyen mansıbı terakki ile istemeğin mülâzemet üzere olmuşdur. 


\section{Ve Mevlânâ Mukarreb}

Ki yirmi akçe ile Karadağ kazâsından ma'zûldur. "Bir yıl yedi aydır ma'zûl mülâzemet iderîn zamân-ı mülâzemetimde güvâhla matlabımda kadılıklar düşûb bazını kendü mülâzımlarına ve bazını gayri mülâzımlara tevcîh edib beni mahrûm etdi. İki def'a Ferecik kadılığı düşdü. İkîsini dahî kendü mülâzımlarına tevcîh etdi. Ve iki def'a Böğürdelen kazâsı düşûb bir sene de Kâdrî Efendi mülâzımına ve bir sene de kendü tezkirecîsine tevcîh etdi. Ve Pınarhisar kazâsı düşûb bir mücrim kimesneye tevcîh etdi. Ve Limni kazâsı düşdü ânı dahî bir mülâzım olmâmış kimesneye tevcîh etdi. Her birinde imtihân taleb etmişdim. Beni imtihân dahî etmedi" didükde, cevâb: Ferecik kazâsı evvel düşdûğı vakit mezbûrun altı ay mülâzemeti vâr idi. Ve verilen mülâzımın bir yıl sekiz ay müddet-i mülâzemeti vâr idi. Def'a-i sâniyede verilen istikâmetde ve diyânetde ve 'ilimde her vechle mezbûrdan ehak olmağîn tevcîh olunub sadaka buyurulmuşdur.

Ve Böğürdelen evvel düşdûğü vakit mezbûrun altı ay müddet-i mülâzemeti vâr idi. Verilen mülâzımın bir buçuk yıldan ziyâde müddet-i mülâzemeti vâr idi. Ve hem diyâneti dahî mezbûrdan râcih idi. Def'ayı sâniyede mezbûrun bir yıl müdddet-i mülâzemeti vâr idi. Ve verilen tezkireci olub sefer-i hümâyunu bile seferledûgunden gayrî bir yıl üç ay müddet-i mülâzemeti vâr idi. Ve Pınarhisar kazâsı düşdüğünde kendünün dokuz ay müddet-i mülâzemeti vâr idi. Verilen kimesnenin cerîmesin bilmeziz. Fevt oldu deyû yeri verilûb ve derfterdârlar mâl-ı pâdişâhı hizmetinde sâ'îdir didikleri sebebden verilmişdir. Ve hem mansıb verilenler asıl mülâzımlerdir. Mevâli-i 'ızâmdan mülâzımlerdir. Mezbûr mukarreb merhûm Mevlânâ Hidâyetin 'umûmundan mülâzım olmuştur. Ve Limni kazâsı düşdûkde verilen kimesne ile zamânları mütekarrib idi. Lakin verilen kimesne yirmi beşden ma'zûl idi. Ve mezbûr mukarreb yirmiden ma'zûl idi. Mislîile istedûği sebebden vech ve müstekım ehl-i 'ilm olmağın istihkâkı üzere tevcîh olunub Âsitâne-i Sa'âdete 'arz olunub sadaka buyruldu. Zâtlarında ve zamânlarında ve mülâzım oldukları maddelerde verilen menâsıba mezbûrdan ehak idüklerinde kıt'â iştibah olmâmağîn imtihân olunmamışdır.

\section{Ve Mevlânâ Sinân ki}

Delvine kazâsından ma'zûldur. "Beni rûznâmede iki ay kâlmağîn ferâğat etdi deyû 'azl etmişsin. Ferâğat etmedûm deyû yemîn etdûkde" cevâb: Rûznâme görüldükde müddetinden kırk gûn kalmış bulunûb ve ol zamânda mezbûr kadılığında olmayûb Âsitâne-i Sa'âdet'de olmağın kırk günde kadılığına vârmağa kâbiliyyet olmadığı ecilden feragat etmişdir. Hâliyen yalân yere yemîn etmişdir. Ve ol zamân Âsitâne-i Sa'âdet'de olması feragatine delildir. Ve ol mikdar zamân tamâm addolunmâk dahî vârdır.

\section{Ve Mevlânâ 'Imâd Sinân}

Ki otuz beş akçe ile kazâ-i Aydos'dan ma 'zûldur. "Kâdıasker oldukları zamânda fakîr otuz akçe ile İvranya kazâsından ma'zûl idim. Yevmî otuz beş akçe ile Aydos 
kazâsı verilip kıdemle ma'zûl olub bir yıldır mülâzemet iderîn. Menâsıb tevzî'inde 'adâlet üzerine olmayûb Yazıcızâde Mevlâna Mehmed'i yirmi beş akçelik kadılıkdan ma'zûl bulûb terakkîler edib hâliyen elli akçe ile Zihne kadısıdır. Ve Kara Recep nâm kimesne otuz beş akçelik kazâda bulunûb suhtesi olmâğın terakkiler edib hâliyen yüz akçe ile Budin kadısıdır. Ve Behrâm nâm kimesneyi otuz akçelik kazâda bulup hâliyen altmış akçe ile Esferâdîn kazasından ma'zûldur. Ve bu hakîr, müftü efendi kadıasker iken tezkirecisi idim. Benden beş yıl sonra kendû tezkireci edindiği Sinân, otuz akçe ile kazâ-i Silivriden ma'zûl idi. Çorlu kazâsı düşdü taleb ettim, banâ tevcîh etmeyûb mezbûr Sinan'a tevcîh etdi. Ve İvranya kazâsı düşdü talep ettim banâ tevcîh etmeyûb âhara tevcîh etdi" didukde, cevab: Ehl-i 'ilm ve sâlih ve mütedeyyin ve müstakim olub yollarıyla mevâli-i 'ızâmdan mülâzım olub ve hal-i pâdişâhîde sâ'yi olub kemâl-i istihkâkları olanlara iltifât-ı pâdişâhî olub terakkiler olmak kânûn-ı kadîm-i Pâdişâhîdir. Ve ba'zı kadılıklar vârdır ki uç ve bihâsıldır. Kimesne gitmemek sebebîyle silsile lâzım olub ve ba'zı kadılar müddeti ile ma'zûl olub terakkiyle verilmek lâzım olur. Ve ba'zı kadılıklarda mâl-ı Pâdişâhî olub nâzar lâzım olmâğla kadısı olana âhar yere terakki lâzım olub silsile olur. Ve ba'zı kadılıkların mâl-ı Pâdişâhiye sa'yi olub mal-ı Pâdişâhîye sâ'yi olanlara terviç için terakki lâzım olur. Ve ba'zı kadılıklar vâki' olub ol matlabda taleb bulunmaz. Eşfasında çok mülâzemet etmiş ba'zı kimesneler bûluna anların için silsile lâzım oldukda yolu ile mevâli-i 'ıâmdan mülâzım olanları ve kemâl-i istihkâkları olanları ve aslâ şikâyetçileri gelmeyenleri bildiğimiz üzerine vâkı' oldukça mâ hüvel-vâkı' Âsitâne-i Sa'âdet'e 'arz edib terakkiler buyurulur. Evvela mezbûr Yazıcızâde Müfti Efendi'den mülâzım olub ilm-i salâh ve diyânet ve takva ile mevsûf olub düşdükçe kânûn üzere terakkiler olmuşdur. Ve merkûme Kara Recep, merhûm Mevlânâ Kemâl Pâşâzâde'den mülâzım olub aslâ bu fakirin suhtesi olmâmışdır. Ve 'âlâkası dahi yokdur. Kadıaskerlik sadaka buyuruldûğu zamân otuz beşlikde olmayûb elli akçe ile Drama kadısı idi. Kazâ-i Eskaradin mahlûl olub uç olmağın, kimesne getmeyib yevmî altmış akçe ile mezbûra sadaka buyurulûb kazâ-i mezbûrdan ma'zûl oldukda altı ay mülâzemet etdi. Sonra yetmiş akçe ile Malkara kazâsı sadaka buyurulûb Malkara Kazâsı müfettişi ve emvâl-i pâdişâhi olan Mevlânâ Hüsrev lâzım olmağın seksen akçe ile Hayrabolu kazâsı sadaka olunub Budin kazâsı mahlûl oldukda uç bî-hâsıl olmâğın kimesne getmeyib terakkiye kemâl-i istihkâkı ma'lûmumuz olduğundan gayrı uç yerlere icrâ-yı şer'ı için cerî ve müstakîm kadı lazîm olmâğın yevmî yüz akçe ile sadaka buyurulmuşdur. Ve mezbûr Behrâm dahi sabıkan Mahrûse-i İstanbûl kazâsından ma'zûl olan merhûm Mevlânâ Hasan Çelebi'den mülâzım olub ğulâm-ı pâdişâhî ve maslahatgüzâr ve mustakîm ve her mertebede terakkîye istihkâkı ma'lûmumuz olmuş, ehl-i 'ilm oldûğuna binâen düşdûkçe kânûn-ı pâdişâhî üzere terakki buyurulmuşdur. Ve bu fakîrin tezkireciliğinden mülâzım olub yevmî otuz akçe ile Seluri kazâsından ma'zûl olan Sinân, Çorlu mahlûl oldukda, çorlu kazâsı defter-i hâkânide yevmî otuz beş akçe olub ve mezkûrun matlabı dahî otuz beş akçelik olub merkum 'Imâd Sinân kırk akçe ile taleb edib ve defterdâr efendiler mal-ı pâdişâhî husûsunda ber- 
vech-i el-'adîle mezkûr Silivri'den ma'zûl olan Sinân'ın sa 'yî ve kifâyeti vârdır deyû taleb edib ve kemâl-i istihkâk ile müstehak olduğûna binâen defter-i hâkânide mukayed oldûğu üzere yevmî otuz beş akçe ile Âsitâne-i Sa'âdet'e 'arz olunub sadaka buyuruldu. Ve İvranya kazâsı defterde otuz beş akçe olmağın yine otuz beş ile 'arz olunub sadaka buyurulmuşdur. Ve mezbûr 'Imâd Sinân'ın diyânetine 'itimâdımız olmayûb her yere ki kadı ola şikâyetçileri eksik olmayûb ve bazı kazâya ya istihdâm olundukda mütehâssımız mezbûrun kazâsından dahî değiliz zîrâ istikâmeti yokdur. Beyne'n-nâs ehad-ı mütehasımîne meyl ile meşhûrdur didûkleri sebebden terakkî olunmadı. Hatta meclis-i teftişde nîce kimesneler mezbûr Imâd Sinân "dûgûn edib 'alâniyete menhî çalkûlar çâldırmışdır" deyû muvâcehesinde haber vîrdîler. Ve rûznâmede dahî bunun emsâli nîce terakkiler vârdır. Bazısı nûrhadeka? saltanat-ı şehzâdeler hazretleri Teâlâ bekâühüm şefâ'atnâmeleriyle ve bazısı hân şefâ'atiyle ve bazısı mal-ı Pâdişâhîye müfettiş temyîz etmekle ve bazısı mehânif teftîşine istihdâm ile ve bazı vilâyet yâzmağa emr olunmak ile ve müfettiş mal-i pâdişâhî olanlara ve mâl-ı Pâdişâhîye sa'yi olanlara tervîc için terakkiye 'arzları ve terbiye nâmeler virmek ile ve bazıların zâtâ ve zamâna istihkâkları ile ve bazının yerleri lâzım olmağla ve sefer-i hümâyûna tevcîh buyuruldukda kâbil-i kadılıklar olub talebler dahî olmayûb yirmi beş ve otuz ve kırk akçe kadılıklara taleb olub rikâb-ı hümâyûnda mülâzemet idenler kandeliği ma 'lûm olmayanlardan mukaddem olmâğın emr-i pâdişâhi ile nice silsileler vâki' olmuşdur. Ve nice medreseler ber-mûcib-i şart-ı vâkıf 'arzları ile ve terbiyenâmeler ile istihkâkları üzere 'arz olunub sadaka buyurulmuşdur. Ve lakin bu makûle tafsilât rûznâmelerde tahrîr olunmak mu'tâd olmâyûb bizden evvel gelenlerin rûznâmeleri hod dahî îcâz üzeredir. Ve terakkiler içün vâki' olan 'arzların ekseri bunda kalân battal 'arzlar içinde bulûnub müfettiş efendiye gösterilib teslim olunmuşdur. Ve aslâ mülâzım olmayub ve mansıb tasarruf etmeyenlere mansıb tevcîh olunmamışdır. Amma mansıbda bulunanlar ber-mûcib-i emr-i Pâdişâhî istihkâkları üzere tarîkinden âhara ihraç olmayûb mansıb tevcîh olunmuşdur. Ve ber mûcib-i şart vâkıf mansıb sadaka buyurulanların zeylinde "tarîka duhûl etmemek şartıyla sadaka buyurulmuşdur" deyû kayd olmuşdur. Ve tarakkîler ki vâki olur müstehaklara olmuşdur. Sâbikan rûznâmelere ve kânûn-ı kadîme muhâlif bir kaziyye vâkı olmâmışdır. Rûznâmeden ve istiksa tarîkiyle yazdıkları maddelerde cümlesine cevablarımız bunlardır.

\section{D_05789_0001_00_003}

\section{Mansıba Duhûl İtmeyen Mülâzımîn Zümresinden Mevlânâ Muhyiddin}

Ki Mevlânâ Kâdirî Efendi'den nevbette mülâzımdır. “Dört yıl mikdârı zamândır mülâzemet iderin. İç-il medreselerinden nîce medâris dûşdü. Bazını kendü mülâzımlarına ve bazısını gayrılara tevcîh edib beni mahrum eyledi" dîdükde, cevab: Iç-il medreselerini habs ile imtihân edib görülmeden verilmez idi. Mezbûr Muhyiddin aslâ imtihâna gelmez idi. Lakin 'azlimizden bir ay mikdârı evvel mutavvele müte'allık bir risâle getirdi. Kendinin idûğü dahî ma'lûmumuz olmadı. 


\section{Mısır kadısı iken fevt olan merhûm Mevlânâ Abdulkâdir'in dânişmendleri}

"Biz cümlemiz mülâzım olub amma nevbetimiz ve intihâbımız ta yîn etmede nizâ'mûz olub hocası oğlu hemşehrileri de ri'âyet için bize düzenlik edin deyûb biz dahî düzenlik edûb mezbûr duzenliğimiz mülâzımîn defterine kayd olunub sonra mülâzım defterinden ihraç edib Pâdişâh-ı 'âlem-penâh size imtihân emr eyledi deyû cevâb virdi" dediklerinde, Cevab: Pâdişâh-ı 'âlem-penâh hazretleri sa'âdetle sefer-i hümâyûna buyurub Sivâs'a varıldığında Dâvud Pâşâ'nın esâmi defteriyle 'arzı gelûb Âsitâne-i Sa'adet'e 'arz olundukda cem'îsi mülâzım olmak emr buyurulûb ama niyâbet ve intihâb ve 'umûm sefer-i hümâyûndan gelinûb cem' olduklarında ta'yîn oluna deyû fermân olmuşdu. Ba'dehû sa'âdetle İstânbul'a gelinûb ve merhûmun dânişmendleri cem' olduklarında niza'ları munkati olmayûb nice zamân muhâlefetleri mümted oldu. Âhar kendü reyleri ile biz düzenlik edib düzenliklerini gelûb takrîr eylediklerinde bu fakîr, tezkireciye "defter ile Anadolu Kadıaskerine gönderelûm müşâvere idelûm" dedikde tezkireci sehven mülâzım defterini vâki oldukça esâmi-i mülâzımîn kaydolunub tamâm oldukda, beyâz olunmak üzerine olan mücellid müsevvide defterine kayd edib ve mezbûrûn dânişmendler dahî ba'dehû nice zamân gelmeyûb ahz-ı düzenlikleri mukarrer olmâğçün pâdişâh-ı gerdûn iktidâra 'arzuhâl sûnduklarında düzenlikleri makbûl olmayûb imtihân olunub bî-hasbil istihkâkım üç nevbet ve altı intihâb ve sârî-yi umûm olmak buyurulûb arzuhallerinde deftere mukayyed olmuş dîdikleri sebebden defter yoklanûb mezbûr defter-i müsevvede de yazılmış bulunûb, tezkireciye "emr olunmadın nîçûn deftere kayd eyledin" deyincek "sizin defter iden dedîgûnûzden ğalat edib mezbûr müsevvede defterine yazmışsın" deyû cevâb virûb hilâf-ı kânûn ve hilâf-ı emr olmâğîn tashihi dahî bu fakîre lâzım olub tashîh ve ıslâh îçûn mezbûr defterden ihrâc olunmuşdur.

\section{Mevâlî-i Mevt Dânişmendlerinden}

Merhûm Mevlânâ Hâfız dânişmendlerini imtihân edib eşbehlerinden nihâyeti on beşe vârınca almak buyurulûb cümleniz cem olub ittifâkınız ile bir defter götürün. Cümlenûz görülüb on beşe vârınca eşbehlerîniz ber mûcib-i emr-i celîlü'l-kadr alınsın denildikde, ahz-ı ittifâkları ile bir defter götûrûb defterde mevcûd olanları Anadolu Kadıaskeri ile imtihân edib istihkâkları üzere içlerinden dokuz nefer dânişmend ve merhûmun oğlu mülâzemete ta yîn olunub ve ğâyet eskilerinden kadîm oldukları cihetden beş kimesne 'arz olundukda umûm mülâzımı olmak buyuruldu idi. Bâkıyesi mülâzım olmayacak meclise gelûb mülâzım ta'yîn olanlara kimine "ehl-i cihet ve kimine irtibatı sâbit degûldür1 deyû isnâdlar edib fî nefsi'l-emr isnâd eyledikleri kazâya dahî sâbit olmayûb 'arzları tekrâr görülmekdir.

Ve İstanbul Kadılığından ma'zûl olub Semâniye Medreselerinden birinde müderris iken fevt olan merhûm Hasan Çelebi'nin ve Edirne kadılığından 
mütekâiid iken fevt olan merhûm Mevlânâ Çelebi'nin ve Bağdâd kadısı iken fevt olan merhûm Mevlânâ Kemâl Çelebi'nin dânişmendlerinden zamân-ı i'tibâr olunmayûb istihkâkları ile on beş kimesne mülâzım alınûb bâkıyyesi mevâlîden 'umumâ nevbet mülâzımı alındıkda görüle deyû fermân olunmuş idi. Mezbûr mülâzemetden kalân dânişmendler mülâzım alındıgı zamânda isbâta muhtâç olmayalûm hâliyen ma'lûmunûz olduğu üzere isimlerimiz yazılsın deyû tazarru'lar eyledikleri ecilden fî nefsü'l-emr lâzım dâhi değil iken hâliyen mülâzemetden mahrûm olub ba'de bârî ta'ab çekmesûnler deyû yâzılmağa tecvîz olunmuş idi. Binaen 'ala zalik tezkireci şerhleri ile müsvedde olan defterin zuhûruna Kemâl Çelebi'nin ve Mevlânâ Çelebi'nin dânişmendleri yazılûb ve mevlânâ Hasan Çelebi'nin dânişmendleri yazılmamış bulundu. Ve hâliyen gelib şikâyet eden dânişmendler ol zamân Anadolu Kâdıaskeri ile ma'â imtihân edib kemâl-i cehilleri zâhir olanlardır. Hâliyen mülâzım olmadıklarına harâretlerinden meclise gelûb envâ'-ı kelimât ve atâlâ etmişlerdir.

\section{Ehli Cihâtdan Gelen Bunlardır}

Mahrûse-i İstanbûl'da merhûm Hüseyin Ağâ Mu'allimhânesi'nin mu'allimi "ta'limimi bilâ sebeb ve 'adem-i istihkâkım ma'lûm olmâdan alıb nâmahall bir kimesneye tevcîh etdi" didükde, cevâb: 'Arzı makbûl olan nâzırın 'arzı ile âhara sadaka buyurulmuşdur. Âharın 'arzı ile olucak istihkâk ve 'adem-i istihkâkı ma'lûm edinmek lâzım değildir.

\section{Muhyiddin Nâm Kimesne}

Ki merhûm Sultân Mehmed Hân teğammedellahu bi'l-gufrân câmi'-i şerifi müezzinlerindendir. "Kasaba-i Çorlu'da bir mezra'a mahlûl olub bu fakîre sadaka buyurulmuşdu. Hâliyen bilâ sebep âhara tevcîh etmişlerdir" didükde, cevâb: Fakîrin tevcîhî ile olmâmışdır. Ama salihâdan Beşiktaş'da sâkin bir sâlih kimesneye mezbûr müezzinden müstehak olmağın Dîvân-ı 'Âlî'den sadaka buyurulmuşdur.

\section{Kara Hasan Nâm Kimesne}

"Mahrûse-i İstanbul'da vâki' olan merhûm Cânbâz Mustafa evkâfına mütevelli idim. Vâkıf ve vakfiyesinde cihet-i tedrîs yevmî on üç akçe ve cihet-i talebe yevmî altı akçe olmak üzere evvela eğer mahsûl-ü evkâf müsâ'id olur ise cihet-i tedrîs yevmî yirmi akçe ve cihet-i talebe yevmî on akçe ola deyû şart etmeğîn sâbikan mahsûl-i evkâf müsâ'id olub yevmî yirmi akçe ile vîrilmiş îdî. Ba'de ğalle-i vakfa naks gelûb medrese-i mezbûra dahîyevmîyirmi akçe ile verilmiş bulunûb ol 'asırda Rumeli Kâdıaskeri olan merhûm Mevlânâ Muhyiddin Çelebi'ye vârûb adem-i müsâ'adesin i'lâm etdigimde aslâ mukayyed olmayûb ve ol 'asırda mahrûse-i İstanbul kadısı olan merhûm Mevlânâ Sa'dî Çelebi kaziyye-i i'lâm eylediğimde "asl-ı mâl-ı vakıfdan ver, sonra mahsûl-i vakıfdan yerine koyasın" deyûb bu minvâl üzere olsûn deyû elime hüccet verib mûcibi ile asl-ı mâl-ı vakıfdan otuz dört bin akçe harc alınıb sonra Buhuri nâm bir kadı müfettiş ta'yin olundukda hüccet 
ile 'amel etmeyûb hilâf-ı şart-ı vâkıfı itlâf eylemiş. "Sen vâr vîrdûgûn yerden al" deyû meblağ-ı mezbûru bana ödedmiş îdi. Hâliyen ol deyn zimmetimdedir deyû dîvân-ı 'adâlet 'unvâna vârûb hâlimi i'lam eyledûgumde, Anadolu Kâdıaskeri Mevlânâ Sinan Çelebi müfettiş ta'yîn buyurulûb anlar dahî teftîş edib cem' akvâlimi takrîrime mutâbık bulûb hâlimi sa'adetlû pâşâ hazretlerine i'lâm edecek, kendi mesârife sarf etmeyib yine mesârif-i vakfa sarf eylediğim ma'lûmları olduğuna binâen merhamet edib buna tedârikündür deyû buyurdukları zamân müşârun ileyh Sinân Çelebi Efendi meğer "tevliyeti yine bunlara ihsân buyurasız, harac eyledüğü mablağı cihet-i tevliyet ve zevaid-i vakf ile yerine koyub tekmîl ede" deyû cevâb verecek 'arz edin deyû işâret buyuruldukda, anlar dahî "'arz benim 'uhdemde değildir. Rumili Kâdıaskeri'nindir" deyûcek. Rumeli Kâdıaskeri yine tevcîh buyurulûb siz 'arz edin deyû buyurduklarında emirleri üzere 'arz etmeyûb bana hayf olmuşdur" didûkde, cevâb: Cem' ahvâli benûm ma'lûmum olmâmışdır. "Zâhiren mal-i vakfdan otuz dört bin akçe itlâf edib cerîme ile ma'zûl olan mütevellinin ahvâli ma'lûmum olmadın. Âsitâne-i Sa'adet'e 'arza kâdir değilim" deyû ol vakitte dahî cevâb verilmişdür.

\section{Hâliyen Meclis-i Teftişe Hâzır Olmayan Hayreddin’in Kaziyyesidir.}

Sâbıkan sefer-i hümâyûnda yirmi beş akçe ile Grebene kazâsından ma'zûl olub mülâzemet üzere iken otuz akçe ile Lofça Kazâsı sadaka olunub sefer-i hümâyûndan gelindikde Şam kazâsından ma'zûl olub bu fakîre müfettiş ta'yîn olunân Mevlânâ Şemseddin'e ol zamân Şam kazâsı sadaka buyurulmuşîlî. Mezbûr Hayreddin için "bize müte'allıkdır, Anadolu'ludur ve hemende vârması lâzım olmuşdur. Anadolu Efendisi ile dahî söyleşdim mansıb tedârikindedir" demişler îdî. Bu fakîr dahî Anadolu Kâdıaskeri hidmetlerinden istinsâr etdiğimde fi'l-vâki' ısmarladılar, tedârik üzerine yazdıkları sebebden müşârun ileyhe müte'allık olub ve mu'temed oldukları ecilden kavilleri makbûl olub mâ hüve'l-vâki pâye-i serîr-i 'alâya 'arz olunub Anadolu'ya geçmek ricâsıyla âhara sadaka buyurulmuşdu. Ba'dehû mezbûr Hayreddin gelûb geri mansıb sadaka buyurulûb gitmişdir. Hâliyen bunda dahî değildir. Lakin rûznâme okundukda tezkireci rûznâmenin bir yerinde "hâliyen Şam kadısı olan Mevlânâ Ahmed Anadolu'da olması lâzım olmâğın feragatın i'lâm etdiği sebebden 'azl buyuruldu" deyû yazmış. Ba 'dehû mezbûr mansıb sadaka buyurulduğu yerde Anadolu'ya tevcîh etmekle ma'zûl olan denilmiş ve mezbûr müfettiş Anadolu'ya tevcîhini i'lâm edib "Anadolu Kadiaskeri ile söyleşdim ama ferâğatin i'lam etmedim" dediğinde tezkireci dahi Anadolu'ya tevcîh edib Kadıasker ile söyleşmeği feragat hükmünde olmak zan edib "bir yerde feragat yazdım ve bir yerde Anadolu'ya tevcîh etmeğide yazdım" deyû cevâb verib hilâf-ı vâki' olanları rûznâmeye kayd olunmuş deyû defterlerine yazdıkları ecilden mâ hüve'l-vâki' tahrîr olundu.

Seyyidü's-Sadât Nakîbü'l-Eşrâf cânibinden sâdâtdan birîne kimesneler gelûb "müşârun ileyh nakîbin hilâf-ı şer' kaziyyesini hükm edib tahfîf edib muhzır ve çâvuş gönderdi" didüklerinde, cevâb: Hâşâ ben sâdâta tahfîf etmedim ve tahfîf 
edib mahzar dahî göndermedim deyû yemîn edib ve çavuşlar Kadıaskerler sözüyle kimesneye varmazlar ben ana kâdir değilim. Ehali ile cümlesi bana bühtândır ve anlara müte allik kaziyye dahî hükm olunmamışdır. Lakin yanımızda Mevlânâ Samsunizâde'nin anların kaziyyelerine müte'allık hüccetinin mazmûnu sâbık olub şer'î idiği ma'lûmumuz olmağın tenfîzi için bir hüccet verilmişdir. Ve zikrolunân hüccetler meclis-i teftişe gelib hilâf-ı şerîi idiği dahî zâhir olmâmışdır.

Ve müteferrika zümresinden Pervâne Bey oğlu Muhammed Bey meclise gelûb "züemâ zümresinden Kara Ali ile Seluri kurbunda olan çayır husûsunda husûmetimiz olub pâdişâh-ı gerdun-ı iktidar hazretlerine ihzâr-ı husemâ kalûb da'valarını istima' edib hak, Kara Ali'nin olub Kara Ali'ye hükm etmeye müteveccih olmuş îken benden "arz eylediler" deyû i'lâm etdüğü sebebden sa'adetlü pâdişâh hazretleri çayırı Kara Ali'ye virdiler" dîdûkde, cevâb: Hâşâ ben da'valarını dinlemedim ve hükm etmedim. Âsitâne-i Sa'âdet'e hilâf-ı vâki' kaziyyede arz etmedim. Lakin kaziyyeleri Anadolu Kadıaskeri tarafından görülmeğin Âsitâne-i Sa'âdet'e 'arz etdüklerinde arz-ı miri olacak Kara Ali'ye vermeye şer'an kâdir olurmuyuz deyû buyurduklarında, şol gerçi meşû'lar anın üzere hâk-i pâyi şeriflerine i'lâm olunmuşdur. Ve husus-ı kaziyye-i pâdişâh 'âlempenah hazretlerinin 'ilm-i şerifleri muhîtdir.

\section{D_05789_0001_00_004}

\section{Üsküblü Ömer Nâm Kimesne}

Ahrîzâde Mevlânâ Muslihiddin, vilâyetimiz kadısı iken "bazı kimesneler benden otuz bin akçe da'vâ etdikde isbâtı îçûn ve hâtûnumu benden boşdur deyû şâhidler şâhâdet etdikde, şâhidlerin sebeb-i cerhini istimâ' etmedin, hükm edib beni nice zamân habs edib cemi' esbâbımı kıymetinden eksiğe satdırıb enva'- zulumler ve te'addîler edib Âsitâne-i Sa'âdet'e gelûb şekvâ etdiğimde görülmesi için Sofya ve Üsküb kadılarına hükm verilib varıb görüldükde kadının biri 'arz edib ve birinin "arzı gelmeyib, "gelmeyen "arz dahî lâzımdır" dedikleri ecilden ben 'arz götûrmeye gedib hasımlarıma istinâf olunmaya deyû hükm vîrmişler. Tekrâr hükm taleb etdiğimde hükm vermeyib benim mazlûm idiğim görülmedi" dîdûkde, cevâb: Hasımları cem'-ı kaziyyeleri şer' ile görülüb fasl olunmuş deyû sâbıkan görülmek için hükm verilen Sofya ve Üsküb kadıları ve Üsküb'de mütekâ'id olan Mehmed Bey'den 'arzlar götürûb pâye-i serîr-i a'lâya 'arz olundukda ber-mûcîb-i şer'-i fasl olunân kaziyyelerin cümlesi istinâf olunmaya deyû 'fermân olunmağın hükm verilmişdir. Mezbûr tekrâr hükm taleb etdiğinde "fasl olunmamış kaziyelerin vâr îse hükm verilsin" denilib istinâf için taleb etdiği ecilden hilâf-ı şer' ve hilâf-ı emr olmâğın verilmemişdir.

Ve eşirrâdan nîce kimesnelerin dört beş yıldan berû görülüb bazısı bermûcib-i şer'-i emr-i pâdişâhî ile ve bazısı nîce dikkatler ile fasl olunân kaziyyeleri ve hâtûnlardan şer'îsini anlamayıb meclise gelenlerin kaziyyeleri için emr-i şerîf vâcibü'l-imtisâlde bu makûle kazâya dahî görülmek fehm olunmaz iken, asla 
muhâlefet olunmayûb her birinde bizzât meclîs-i teftîşe hâzır olub nîce dikkatler ile görüldükde cem isi ber-mûcib-i şer ‘i görüldüğü sâbit olub hilâf-ı şer'î kaziyye sâbit olmâmışdır.

\section{KAYNAKÇA}

\section{Arşiv Belgeleri}

Türkiye Cumhuriyeti Cumhurbaşkanlığı Devlet Arşivleri Başkanlığı Osmanlı Arşivleri (BOA). Topkapı Müzesi Arşiv Defterleri. (TS.MA.d). 5789/1.

Nuruosmaniye Kütüphanesi (NOK). Anadolu Kadıaskerliği Ruznamçe Defterleri(AKR). Eski kayıt 5193/11 (Yeni kayıt 4569/11).

\section{Basılı Eserler ve İncelemeler}

Abdurrahmân Abdî Paşa. Abdurrahmân Abdî Paşa Kanunnâmesi. Nşr. H. Ahmet Arslantürk. İstanbul: Okur Kitaplığı Yayınları, 2012.

Akgündüz, Hasan. Klasik Dönem Osmanlı Medrese Sistemi (Amaç, Yapı, İşleyiş). İstanbul: Ulusal Yayınları, 1997.

Aksoy, Hasan. “Dursun Fakih". Türkiye Diyanet Vakfı İslâm Ansiklopedisi. 9: 7-8. İstanbul: TDV Yayınları, 1994.

Aktepe, Münir. "Çandarlı Kara Halil Hayreddin Paşa". Türkiye Diyanet Vakfı İslâm Ansiklopedisi. 8: 214-215. İstanbul: TDV Yayınları, 1993.

Alan, Ercan. Kadıasker Ruznamçelerine göre XVII. Yüzyılda Rumeli'de Kadılık Müessesesi. Doktora Tezi, Marmara Üniversitesi, 2015.

Âşıkpaşazâde. Âşıkpaşaoğlu Tarihi. Nşr. Atsız. İstanbul: Milli Eğitim Bakanlığı Yayınları, 1992.

Aydın, Mehmet Akif. "Osmanlı Ceza Hukuku”. Türkiye Diyanet Vakfı İslâm Ansiklopedisi. 7: 478-482. İstanbul: TDV Yayınları, 1993.

Baltacı, Cahid. XV ve XVI. Yüzyıllarda Osmanlı Medreseleri. I. Cilt. İstanbul: M.Ü. İlahiyat Fakültesi Vakfı Yayınları, 2005.

Bayraktar, Mehmet. "Dâvûd-i Kayserî. Türkiye Diyanet Vakfı İslâm Ansiklopedisi. 9: 33. İstanbul: TDV Yayınları, 1994.

Beyazıt, Yasemin. Osmanlı Illmiye Mesleğinde İstihdam (XVI. yüzyıl). Ankara: Türk Tarih Kurumu Yayınları, 2014.

Beyazıt, Yasemin. "XVI. Yüzyıl Osmanlı İlmiyye Kanûnnâmeleri ve Medrese Eğitimi". Belleten LXXVIII/283 (2014), 955-981.

Boogert, Maurits H. van den. Kapitülasyonlar ve Osmanlı Hukuk Sistemi 18. Yüzyılda Kadılar, Konsoloslar ve Beratılır. Trc. Ali Coşkun Tuncer. İstanbul: Türkiye İş Bankası Yayınları, 2014. 
Gelibolulu Mustafa Âlî. Mevâ'ıdü'n-Nefâis Fî-Kavâ'di'l-Mecâlis, Nşr. Mehmet Şeker, Ankara: Türk Tarih Kurumu Yayınları, 1997.

Emecen, Feridun. "Bedel". Türkiye Diyanet Vakfı İslâm Ansiklopedisi. 5: 301. İstanbul: TDV Yayınları, 1992.

Furat, Ayşe Zişan. "Fetih Sonrası Osmanlı Eğitim Anlayışının Şekillenişi: Klasik Dönem Müderrislik İmtihanları". Osmanlı'da Illim ve Fikir Dünyası (Istanbul'un Fethinden Süleymaniye Medreselerinin Kuruluşuna Kadar). Ed. Ömer Mahir Alper - Mustakim Arıcı. 11-31. İstanbul: Klasik Yayınları, 2015.

İpşirli, Mehmet. "Anadolu Kadıaskeri Sinan Efendi Hakkında Yapılan Tahkikat ve Bunun İlmiye Teşkilâtı Bakımından Önemi". İslâm Tetkikleri Dergisi, İstanbul: İstanbul Üniversitesi Edebiyat Fakültesi Yayınları. 8/1-4. (1984): 205-218.

İdris-i Bitlisi. Heşt Behişt VII. Ketibe, Fatih Sultan Mehmet Devri (1451-1481). Nşr. Muhammed İbrahim Yıldırım. Ankara: Türk Tarih Kurumu Yayınları, 2013.

İnalcık, Halil. Osmanlı Imparatorluğu Klâsik Çağ (1300-1600). Trc. Ruşen Sezer. İstanbul: Yapı Kredi Yayınları, 2013.

IIImiye Salnamesi (Osmanlı IIlmiye Teşkilâtı ve Şeyhülislâmlar). Nşr. Seyit Ali KahramanAhmed Nezih Galitekin-Cevdet Dadaş. İstanbul: İşaret Yayınları, 1998.

İpşirli, Mehmet. "Fenârîzâde Muhyiddin Çelebi", Türkiye Diyanet Vakfı İslâm Ansiklopedisi. 12: 339-340. İstanbul: TDV Yayınları, 1995.

İpşirli, Mehmet. “Osmanlı Devleti'nde Kadıaskerlik (XVII. Yüzyıla kadar). Belleten, 61/232: (Aralık 1997): 597-699.

Kaya, Eyüp Said. "Sinan Efendi". Türkiye Diyanet Vakfı İslâm Ansiklopedisi. 37: 228-229. İstanbul: TDV Yayınları, 2009.

Kılıç, Cihan. XVII. Yüzyılın Ikinci Yarısında Osmanlı IIlmiye Teşkilâtında Istihdam ve Hareket (Anadolu Kadıaskerliği Örneği). Doktora Tezi, Yıldırım Beyazıt Üniversitesi, 2017.

Koçi Bey. Koçi Bey Risalesi. nşr. Yılmaz Kurt. Ankara: Akçağ Yayınları, 1998.

Kuru, Levent. Kazasker Ruznamçelerine Göre XVIII. Yüzyılın IIlk Yarısında Rumeli'de Kadılık Müessesesi. Doktora Tezi, Marmara Üniversitesi, 2016.

Nev'izâde Atâyî. Hadâ'iku'l-Hakâ'ik fî Tekmileti'ş-Şakâ'ik (Nev'izâde Atâyi'nin Şakâ'ik Zeyli). I. Nşr. Suat Donuk. İstanbul: Türkiye Yazma Eserler Kurumu Başkanlığı Yayınları, 2017.

Mumcu, Ahmet. Hukuksal ve Siyasal Karar Organı Olarak Divan-ı Hümayun. Ankara: Birey ve Toplum Yayınları, 1976.

Müstakimzade Süleyman Saadeddin. Devhat ül-Meşayih Osmanlı Şeyhülislâmlarının Biyografileri. İstanbul: Çağrı Yayınları, 1978.

Ortaylı, İlber. "Osmanlı Devleti'nde Kadı". Türkiye Diyanet Vakfı İslâm Ansiklopedisi. 24: 6973. İstanbul: TDV Yayınları, 2001.

Pakalın, M. Zeki. Osmanlı Tarih Deyimleri ve Terimleri Sözlügü. 3 Cilt. İstanbul: Milli Eğitim Bakanlığı Yayınları, 1983.

Sahillioğlu, Halil. "Avârız". Türkiye Diyanet Vakfı İslâm Ansiklopedisi. 4: 108-109. İstanbul: TDV Yayınları, 1991. 
Selânikî Mustafa Efendi. Tarih-i Selânikî. Nşr. Mehmet İpşirli. 2 Cilt. Ankara: TTK Yayınları, 1999.

Shaw, Stanford J. Osmanlı Imparatorluğu ve Modern Türkiye. 2 Cilt. Trc. Mehmet Harmancı. İstanbul: e Yayınları, 2008.

Şentop, Mustafa. Osmanlı Yargı Sistemi ve Kazaskerlik. İstanbul: Klasik Yayınları, 2005.

Şentop, Mustafa. Osmanlı Devleti'nde Kazaskerlik Kurumu (XVII. Yüzyılın Sonuna Kadar). Doktora Tezi, Marmara Üniversitesi, 2002.

Uzunçarşılı, İsmail Hakkı. Osmanlı Devleti'nin Ilımiye Teşkilâtı. Ankara: TTK Yayınları, 2014.

Yavuz, Yusuf Şevki. "Hüccet". Türkiye Diyanet Vakfı İslâm Ansiklopedisi. 18: 445-446. İstanbul: TDV Yayınları, 1998.

Zengin, Zeki Salih. "Osmanlı Medreselerindeki Gerilemenin Sebep ve Sonuçları Üzerine Bir değerlendirme". Vakıflar Dergisi, XXVI (1997), 401-409. 
